\title{
Decompression vs. decomposition: distribution, amount, and gas composition of bubbles in stranded marine mammals
}

\author{
Yara Bernaldo de Quirós ${ }^{1,2,3 t}{ }^{1}$, Oscar González-Diaz ${ }^{2}$, Manuel Arbelo ${ }^{1}$, Eva Sierra ${ }^{1}$, Simona Sacchini ${ }^{1}$ and \\ Antonio Fernández ${ }^{1}$ * \\ Veterinary Histology and Pathology, Department of Morphology, Institute of Animal Health, Veterinary School, University of Las Palmas de Gran Canaria, \\ Las Palmas, Spain \\ 2 Physical and Chemical Instrumental Center for the Development of Applied Research Technology and Scientific estate, University of Las Palmas de Gran Canaria, \\ Las Palmas, Spain \\ Biology Department, Woods Hole Oceanographic Institution, Woods Hole, MA, USA
}

Edited by:

Andreas Fahlman, Texas A\&M,

Corpus Christi, USA

Reviewed by:

Neal William Pollock, Divers Alert

Network, USA

Paul David Jepson, Zoological Society

of London, UK

*Correspondence:

Antonio Fernández, Universidad de

Las Palmas de Gran Canaria, Instituto

Universitario de Sanidad Animal,

Facultad de Veterinaria,

C/Trasmontaña s/n. 3, 5416, Arucas,

Las Palmas, Spain.

e-mail: afernandez@dmor.ulpgc.es

${ }^{\dagger}$ Present address:

Yara Bernaldo de Quirós, Biology

Department, Woods Hole

Oceanographic Institution, Woods

Hole, MA, USA.
Gas embolic lesions linked to military sonar have been described in stranded cetaceans including beaked whales. These descriptions suggest that gas bubbles in marine mammal tissues may be more common than previously thought. In this study we have analyzed gas amount (by gas score) and gas composition within different decomposition codes using a standardized methodology. This broad study has allowed us to explore species-specific variability in bubble prevalence, amount, distribution, and composition, as well as masking of bubble content by putrefaction gases. Bubbles detected within the cardiovascular system and other tissues related to both pre- and port-mortem processes are a common finding on necropsy of stranded cetaceans. To minimize masking by putrefaction gases, necropsy, and gas sampling must be performed as soon as possible. Before $24 \mathrm{~h}$ post mortem is recommended but preferably within $12 \mathrm{~h}$ post mortem. At necropsy, amount of bubbles (gas score) in decomposition code 2 in stranded cetaceans was found to be more important than merely presence vs. absence of bubbles from a pathological point of view. Deep divers presented higher abundance of gas bubbles, mainly composed of $70 \%$ nitrogen and $30 \% \mathrm{CO}_{2}$, suggesting a higher predisposition of these species to suffer from decompression-related gas embolism.

Keywords: gas emboli, decompression, putrefaction, gas-off, marine mammals, nitrogen, strandings

\section{INTRODUCTION}

Marine mammals moved from land to water around 55-60 million years ago (Ponganis et al., 2003). Marked anatomical and physiological modifications were necessary to meet the physical demands of living in water instead of air (Williams and Worthy, 2002). These required variations include adaptations for breathhold diving, temperature regulation in cold water, water, and salt balance, underwater navigation, and high pressure at great depth (Elsner, 1999).

Marine mammals have not been considered to suffer from decompression sickness (DCS) because of anatomical, physiological, and behavioral adaptations that help them to prevent gas bubble formation. More specifically compression of the respiratory system together with blood-flow changes during the dive would limit the amount of nitrogen absorbed on a dive (Scholander, 1940; Butler and Jones, 1997; Kooyman and Ponganis, 1998; Fahlman et al., 2006). Compression of the respiratory system was suggested to force the air into the upper airways where no gas exchange should take place, therefore it was assumed that the finite volume of gas available in the lung would not be sufficient to increase the tissue and blood inert gas tension. Finally, partial pressure of nitrogen in the blood would decrease as nitrogen is distributed among tissues (Piantadosi and Thalmann, 2004).
In human breath-hold divers, nitrogen accumulates in tissues as pulmonary nitrogen partial pressure $\left(\mathrm{PN}_{2}\right)$ increases with depth. If the surface interval between repeated dives is insufficient to remove the inert gas, nitrogen accumulation will occur (Ferrigno and Lundgren, 2003). A causal relationship between breath-hold diving in humans and DCS is only slowly being accepted despite the growing number of cases of DCS-like symptoms in breath-hold diving humans (Schipke et al., 2006). Some of these symptoms might include vertigo, visual disturbances, unconsciousness, and partial or complete paralysis of one or more extremity that could be temporary or permanent. When these symptoms respond to recompression, the most reasonable explanation is the presence of bubbles due to gas phase separation in the body (Paulev, 1965). It has been generally assumed that the risk of DCS is virtually zero during a single breath-hold dive in humans, however DCS has also been reported (although unusual) in 2 out of 192 deep single breath-hold dives (Fitz-Clarke, 2009). Diagnosis of both cases was based on DCS symptoms and recovery after treatment in a hyperbaric chamber.

Recent work has suggested that the depth of lung compression is not the same for all marine mammals species (Moore et al., 2011) and one suggested reason is because of anatomical differences of the thorax and even of the lung airways (Belanger, 1940; 
Denison and Kooyman, 1973; Kooyman, 1973). Indirect measurements of nitrogen uptake and removal have suggested that alveolar collapse occurs at between $30 \mathrm{~m}$ (Falke et al., 1985) in the Weddell seals and $70 \mathrm{~m}$ in the bottlenose dolphins (Ridgway and Howard, 1979). However, the physiological assumptions used in these studies are suspect (Bostrom et al., 2008) and direct measurements in seals and sea lions suggest that alveolar collapse and cessation of gas exchange may not happen until depths greater than $100 \mathrm{~m}$ (Kooyman and Sinnett, 1982).

Moreover, intramuscular nitrogen levels as great as two to three times the normal surface levels have been measured in voluntary diving bottlenose dolphins after repeated short duration dives to $100 \mathrm{~m}$ depth (Ridgway and Howard, 1979). Moore et al. (2009) described a high prevalence of bubble lesions in bycaught seals and dolphins trapped at depth (15 out of 23) compared to stranded marine mammals ( 1 out of 41 ), probably due to off gassing from supersaturated tissues. In addition, several theoretical studies have predicted end-dive nitrogen levels for marine mammals that would cause a significant proportion of DCS cases in land mammals (Houser et al., 2001; Zimmer and Tyack, 2007; Hooker et al., 2009).

In the last 8 years, an increasing number of studies have reported lesions related to in vivo bubbles. Systemic venous gas emboli were first described in an atypical beaked whale (BW) mass stranding related to military maneuvers that occurred in the Canary Islands in 2002. BWs ( 8 out of 8 ) presented acute lesions consistent with acute trauma due to in vivo bubble formation (Jepson et al., 2003; Fernandez et al., 2005). Chronic gas bubble lesions were also reported in single strandings of Risso's dolphin (3 out of 24 ), common dolphins ( 3 out of 342), harbor porpoises ( 1 out of 1035), and in a Blainville's BW (1 out of 1) stranded in the United Kingdom (Jepson et al., 2003, 2005). Further gas analyses from one Cuvier's BW stranded along the Spanish coastline in temporal and spatial association with military (naval) exercises and one UK-stranded Risso's dolphin with chronic gas embolic lesions in the spleen, have confirmed high nitrogen content, of around 95\% in the Risso's dolphin case (Bernaldo de Quirós et al., 2011). Additionally, dysbaric osteonecrosis (a chronic pathology of deep diving recognized in humans) has been described in sperm whales (Moore and Early, 2004). Finally, a recent publication showed the existence of intravascular bubbles and peri-renal subcapsular emphysema (gas found beneath the kidney capsule) in live stranded dolphins using a B-mode ultrasound (Dennison et al., 2012).

Given these recent observations, it is valuable to review the diving behavior of cetaceans. Some species of BWs have dive profiles not previously observed in other marine mammals such as very deep foraging dives (up to $2000 \mathrm{~m}$ and as long as $90 \mathrm{~min}$ ), and relatively slow controlled ascents followed by a series of bounce dives of 100-400 m (Hooker and Baird, 1999; Tyack et al., 2006). These diving profiles are considered as extreme dives and alterations of these dive sequences by a behavioral response might induce excessive nitrogen supersaturation driving growth of bubbles in a manner similar to DCS in humans (Cox et al., 2006). Indeed, it was in BWs stranded in spatiotemporal concordance with military maneuvers when the "gas bubble lesions" were described for the first time (Jepson et al., 2003; Fernandez et al., 2005). Authors suggested a DCS-like disease as a plausible mechanism for explaining the observed lesions. These findings have been widely discussed since then and have become a scientific controversy. Further investigations, including analysis of gas in bubbles were recommended (Piantadosi and Thalmann, 2004).

Here we present a comprehensive study of prevalence, amount, distribution, and composition of intravascular bubbles and subcapsular emphysema found in cetaceans stranded on the Canary Islands coast, Spain, with different decomposition codes. The waters of the Canary Islands are one of the richest and most diverse areas in the Northeast Atlantic, with 28 different cetacean species reported, 21 of the Odontocete and 7 of the Mysticete group. Of these 28 species, at least 26 have been found stranded on the coasts of the Canary Islands (Martin et al., 2009). The high biodiversity, including both shallow and deep diving species, make the Canary Islands an excellent natural laboratory for the study of gas emboli in cetaceans with different diving behaviors.

\section{MATERIALS AND METHODS MATERIALS}

Animals included in the study were stranded cetaceans in the Canary Islands between 2006 and 2010, mass stranded sperm whales in Italy in 2009, and two sea lions (Otaria byronia) from aquatic-parks of the Canary Islands submitted for necropsy to our institution. A total of 88 necropsies were performed on marine mammals belonging to 18 different species. Species were segregated into two broad groups: deep divers and non-deep divers, defining deep divers as those species known to dive deeper than $500 \mathrm{~m}$ for foraging (Kogia, Physeter, Ziphius, Mesoplodon, Globicephala, and Grampus; Gannier, 1998; Astruc and Beaubrun, 2005; Aguilar de Soto, 2006; Tyack et al., 2006; Watwood et al., 2006; West et al., 2009). These genera were further studied separately except for Ziphius and Mesoplodon, which were studied together as the family Ziphiidae. Twenty-nine out of 88 (33\%) necropsied animals were deep divers.

Animals were identified by their stranding codes, represented by CET ("cetacean") followed by the stranding number. Animals not stranded in the Canary Islands were identified by their investigation numbers, represented by I ("investigation") followed by their corresponding numbers and the year when their necropsies were performed (Table 1). Cause(s) of death (defined as pathological entities) were determined by the Division of Histology and Animal Pathology of the Institute for Animal Health, University of Las Palmas de Gran Canaria (ULPGC; Unit of Cetaceans Research, 2006, 2007, 2008, 2009, 2010; Arbelo, 2007; Table 1).

\section{METHODS}

At necropsy, putrefaction of the animal was evaluated using a morphological decomposition code from one to five according to Kuiken and García-Hartmann (1991) where one is the animal alive (becomes code 2 at death), code 2 is when the animal is extremely fresh (no bloating), code 3 is moderate decomposition (bloating, skin peeling but organs still intact), code 4 is advanced decomposition (major bloating, organs beyond recognition), and finally code 5 when no organs are present. Dissection, gas sampling and analysis were performed following procedures described by Bernaldo de Quirós et al. (2011). A total of 429 samples were recovered and analyzed from the studied animals, 208 (48\%) of which belong to deep diving animals. 
Table 1 | Identification number of the marine mammals included in the study, biological information, stranding circumstances, storing conditions, decomposition code, and most likely $\left({ }^{*}\right)$ cause of dead established by individual pathological studies.




Table 1 | Continued

\begin{tabular}{|c|c|c|c|c|c|c|c|c|c|}
\hline $\begin{array}{l}\text { Identification } \\
\text { number }\end{array}$ & Species & $\begin{array}{l}\text { Deep } \\
\text { diver }\end{array}$ & Gender & Age & $\begin{array}{l}\text { Active } \\
\text { stranding }\end{array}$ & $\begin{array}{l}\text { Mass } \\
\text { stranding }\end{array}$ & Frozen & $\begin{array}{l}\text { Decomposition } \\
\text { code }\end{array}$ & Cause of dead* \\
\hline CET 435 & Stenella frontalis & No & $\mathrm{F}$ & Adult & No & No & No & 5 & Trauma \\
\hline CET 438 & Steno bredanensis & No & $\mathrm{F}$ & Subadult & No & No & No & 5 & Not determined \\
\hline CET 456 & Grampus griseus & Yes & $\mathrm{F}$ & Adult & Yes & No & Yes & 2 & $\begin{array}{l}\text { Infectious meningoen- } \\
\text { cephalitis }\end{array}$ \\
\hline CET 460 & Stenella coeruleoalba & No & M & Calve & No & No & No & 4 & Trauma \\
\hline CET 462 & Stenella frontalis & No & $\mathrm{F}$ & Calve & No & No & Yes & 5 & Not determined \\
\hline CET 463 & $\begin{array}{l}\text { Physeter } \\
\text { macrocephalus }\end{array}$ & Yes & $\mathrm{F}$ & Neonate & Yes & No & No & 1 & Parental segregation \\
\hline CET 464 & $\begin{array}{l}\text { Globicephala } \\
\text { macrorhynchus }\end{array}$ & Yes & M & Juvenile & No & No & No & 4 & Enterotoxaemia septicemia \\
\hline CET 473 & Steno bredanensis & No & $\mathrm{F}$ & Juvenile & Yes & No & No & 2 & Septicemia \\
\hline CET 474 & Stenella coeruleoalba & No & M & Adult & No & No & Yes & 2 & Septicemia \\
\hline CET 476 & Stenella coeruleoalba & No & $\mathrm{F}$ & Calve & No & No & No & 2 & Chronic renal failure \\
\hline CET 482 & Delphinus delphis & No & $\mathrm{F}$ & Adult & No & No & Yes & 3 & Bacterial bronchopneumonia \\
\hline CET 483 & Grampus griseus & Yes & M & Adult & Yes & No & No & 2 & Venous gas embolism \\
\hline CET 487 & Stenella coeruleoalba & No & $\mathrm{F}$ & Juvenile & No & No & No & 5 & Not determined \\
\hline CET 504 & $\begin{array}{l}\text { Globicephala } \\
\text { macrorhynchus }\end{array}$ & Yes & M & Adult & No & No & No & 4 & Meningitis, septicemia \\
\hline CET 505 & Tursiops truncatus & No & M & Juvenile & No & No & No & 5 & Not determined \\
\hline CET 506 & Stenella coeruleoalba & No & $\mathrm{F}$ & Neonate & No & No & Yes & 4 & Not determined \\
\hline CET 509 & Tursiops truncatus & No & M & Subadult & No & No & No & 4 & Not determined \\
\hline CET 521 & Delphinus delphis & No & ND & Juvenile & No & No & Yes & 5 & Not determined \\
\hline CET 522 & Stenella frontalis & No & M & Adult & No & No & Yes & 3 & Toxoplasmosis \\
\hline CET 523 & $\begin{array}{l}\text { Balaenoptera } \\
\text { acutorostrata }\end{array}$ & No & M & Calve & No & No & No & 2 & Parental segregation \\
\hline CET 526 & Tursiops truncatus & No & $\mathrm{F}$ & Adult & $?$ & No & No & 2 & Septicemia \\
\hline CET 527 & Stenella coeruleoalba & No & $\mathrm{F}$ & Adult & Yes & No & Yes & 3 & $\begin{array}{l}\text { Parasitoses Bacterial infec- } \\
\text { tion }\end{array}$ \\
\hline CET 530 & Stenella frontalis & No & $\mathrm{F}$ & Adult & $?$ & No & No & 2 & Trauma toxoplasmosis \\
\hline CET 531 & Stenella frontalis & No & M & Juvenile & $?$ & No & No & 2 & Septicemia \\
\hline CET 533 & Grampus griseus & Yes & M & Adult & No & No & No & 4 & Not determined, Parasitoses \\
\hline CET 534 & Grampus griseus & Yes & M & Subadult & Yes & No & No & 1 & $\begin{array}{l}\text { Viral disease, bacterial/ } \\
\text { mycotic infection }\end{array}$ \\
\hline CET 537 & Stenella coeruleoalba & No & $\mathrm{F}$ & Adult & No & No & No & 2 & Septicemia \\
\hline CET 542 & Kogia sima & Yes & ND & Adult & No & No & No & 4 & Septicemia \\
\hline CET 543 & Tursiops truncatus & No & M & Adult & No & No & No & 5 & Senile disease, parasitoses \\
\hline CET 544 & $\begin{array}{l}\text { Physeter } \\
\text { macrocephalus }\end{array}$ & Yes & M & Juvenile & No & No & No & 5 & Trauma, ship collision \\
\hline
\end{tabular}


Table 1 | Continued

\begin{tabular}{|c|c|c|c|c|c|c|c|c|c|}
\hline $\begin{array}{l}\text { Identification } \\
\text { number }\end{array}$ & Species & $\begin{array}{l}\text { Deep } \\
\text { diver }\end{array}$ & Gender & Age & $\begin{array}{l}\text { Active } \\
\text { stranding }\end{array}$ & $\begin{array}{l}\text { Mass } \\
\text { stranding }\end{array}$ & Frozen & $\begin{array}{l}\text { Decomposition } \\
\text { code }\end{array}$ & Cause of dead* \\
\hline CET 546 & Stenella coeruleoalba & No & $M$ & Adult & Yes & No & No & 3 & $\begin{array}{l}\text { Trauma, stranding stress } \\
\text { syndrome }\end{array}$ \\
\hline CET 547 & $\begin{array}{l}\text { Mesoplodon } \\
\text { europaeus }\end{array}$ & Yes & $\mathrm{M}$ & Adult & $?$ & No & No & 4 & Not determined \\
\hline CET 548 & Stenella frontalis & No & $M$ & Calve & No & No & No & 2 & Viral disease \\
\hline CET 549 & Grampus griseus & Yes & $\mathrm{F}$ & Adult & No & No & No & 2 & Venous gas embolism \\
\hline CET 552 & $\begin{array}{l}\text { Balaenoptera } \\
\text { borealis }\end{array}$ & No & $M$ & Juvenile & No & No & No & 5 & Pending \\
\hline |134/07 & Otaria byronia & No & $M$ & Adult & No & No & No & 3 & Not determined \\
\hline |185/09 & Mesoplodon bidens & Yes & $\mathrm{F}$ & Adult & No & Yes & No & 5 & Pending \\
\hline 1344/07 & Otaria byronia & No & $\mathrm{M}$ & Juvenile & No & No & No & 2 & $\begin{array}{l}\text { latrogenic pneumomedi- } \\
\text { astinum }\end{array}$ \\
\hline 1298/09 & $\begin{array}{l}\text { Physeter } \\
\text { macrocephalus }\end{array}$ & Yes & M & Juvenile & Yes & Yes & No & 3 & Not determined \\
\hline I299/09 & $\begin{array}{l}\text { Physeter } \\
\text { macrocephalus }\end{array}$ & Yes & $M$ & Juvenile & Yes & Yes & No & 2 & Not determined \\
\hline 1300/09 & $\begin{array}{l}\text { Physeter } \\
\text { macrocephalus }\end{array}$ & Yes & $M$ & Juvenile & Yes & Yes & No & 2 & Not determined \\
\hline
\end{tabular}

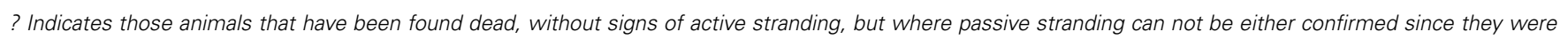
found already dead.

Samples containing blood were considered contaminated, since putrefaction gases from the blood will alter original gas sample composition. When no gas compound had a chromatographic signal higher than the detection limit, the sample was considered empty. In addition, if only one compound was present in slightly higher quantities than the established detection limit, the sample was considered small and not representative of its original composition. Finally samples with an atmospheric-air-like composition (around $79 \%$ nitrogen and $21 \%$ oxygen) were considered as "atmospheric-air polluted." Thus, samples with blood, empty, or identified as small or atmospheric-air polluted were not included in the results. These samples represented $28 \%$ of the total. Most of them were emptied intestines or blood contaminated samples from the heart when only the vacutainer was applied. This problem was prevented later in the study by using an aspirometer (Bernaldo de Quirós et al., 2011).

The amount of gas present in veins and tissues was evaluated retrospectively using pictures and data in the necropsy reports. Gas amount was semi-quantified by giving a score to different vascular locations as well as to the presence of subcapsular gas (emphysema), defined as macroscopically visible gas found beneath the capsule of body organs (e.g., kidneys). Vascular locations studied for gas scoring were subcutaneous, mesenteric, and coronary veins as well as the lumbo-caudal venous plexus. We used the following score for these locations: grade 0 is no bubbles, grade I represented few bubbles and grade II represented abundant presence of bubbles. Prevalence of subcapsular gas, was evaluated with a similar grading system: grade 0 is no subcapsular gas, grade I represented the presence of subcapsular gas in one or two organs, and grade II represented wide distribution through the body organs. The summation of gas score (0-II) in the different vascular locations and tissues (subcapsular gas; $n=5$ ), gave the total gas score for each animal that ranged from 0 to 10 . However, because gas score was done retrospectively, some information was missing on occasion. Those cases on which only one localization could not be scored were marked with an asterisk $\left({ }^{*}\right)$, indicating that the total gas score might be up to two units higher according to the established gas score (e.g., $8^{*}$ ). If information from more than one localization was missing, the total gas score was not reported as it would not be a realistic estimate. Finally, there were some animals with advanced putrefaction where the veins could not be clearly distinguished from the rest of the tissues. Gas score was not undertaken in these cases.

The proportion of observations were analyzed for non-random associations between two categorical variables with the Fisher exact test. Hypothesis testing was considered significant when the corresponding $P$-value was less than 0.05 . All data were analyzed using Sigma Stat software, version 3.5.

\section{RESULTS}

\section{PREVALENCE OF BUBBLES}

Intravascular bubbles were found in 51 out of 88 animals (58\%). They were absent in 33 out of 88 (37\%) and the observation was not correctly undertaken in 4 out of 88 animals (5\%). Bubbles were statistically $(P=0.006)$ more frequently present in deep divers (76\%) compared to non-deep divers (52\%). Subcapsular emphysema (mostly peri-renal) was found in 57 out of 88 animals (65\%). It was found in $66 \%$ of the non-deep diving animals and in $71 \%$ of the deep divers. This difference was statistically non-significant $(P=0.474)$.

A positive relationship between decomposition code and presence of intravascular bubbles and/or subcapsular emphysema was 
found (Figure 1). Intravascular bubbles were present in all the studied animals with decomposition code 4 or higher. However, intravascular bubbles had a higher prevalence $(P=0.006)$ in deep divers compared to non-deep divers regardless of decomposition code (Figures 2 and 3); they were present in 57\% of the fresh (decomposition code 2) deep diving animals compared to $20 \%$ of non-deep divers $(P=0.001)$, and in $100 \%$ of deep diving animals with decomposition code 3 compared to $50 \%$ of non-deep divers within the same decomposition code $(P=0.019)$. In addition, subcapsular emphysema was found in $64 \%$ of the deep divers vs. $44 \%$ with decomposition code 2 , and in $66 \%$ of the deep divers vs. $61 \%$ of the non-deep divers with decomposition code 3 , although these differences were not statistically significant $(P=0.204$ and $P=0.648$ respectively).

In $40 \%$ of the fresh animals with subcapsular emphysema, intravascular bubbles were additionally present, while $61 \%$ of the fresh animals with intravascular bubbles also had subcapsular emphysema.
In freshly dead animals, intravascular bubbles were seen in 7 out of 14 of the cetaceans that were known to strand actively (by swimming ashore) but only in 3 out of 15 that were found floating ashore dead or dead in the beach with no signs of active stranding. Animals found dead but suspected to have stranded alive were not included in the study. Differences were not statistically significant $(P=0.128)$.

\section{AMOUNT OF BUBBLES (GAS SCORE) Non-deep divers}

Gas score from fresh non-deep diving animals was always lower than half of the scale ( 5 on a scale of 10). Forty-four percent of them (11 out of 25) did not present either intravascular bubbles or subcapsular emphysema (gas score 0 ). Gas score of dolphins with incipient autolysis (decomposition code 3 ) varied greatly (from 0 to 7 ). Dolphins with advanced autolysis (decomposition code 4) had gas score ranging from 5 to 8 and potentially 10, while all animals in a very advanced state of autolysis (decomposition code

FIGURE 1 | Number and relative percentage of animals with intravascular bubbles (in dark gray) compared to those without bubbles (in white)

regarding to decomposition code.
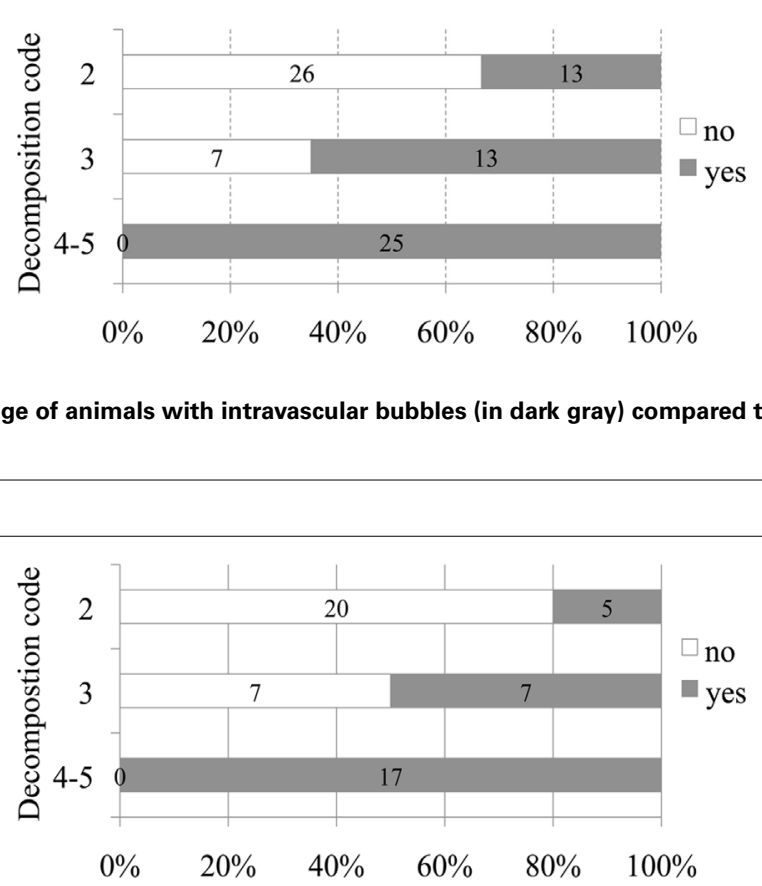

FIGURE 2 | Number and relative percentage of non-deep diving animals in which bubbles were observed (in dark gray) compare to those in which bubbles were absent (in white) attending to decomposition code.

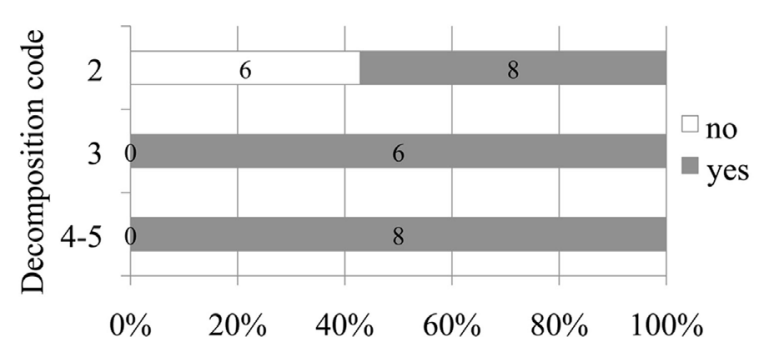

FIGURE 3 | Number and relative percentage of deep diving animals in which bubbles were observed (in dark gray) compare to those in which bubbles were absent (in white) attending to decomposition code. 
5) had the maximum gas score until an advanced state of decay was reached and integrity of the tissues was lost (Figure 4).

\section{Deep divers}

Gas score from fresh deep divers was higher compared to non-deep divers. Thirty-five percent of the animals (5 out of 14) presented gas score 5 or higher. Indeed, two of these animals presented the highest gas score of all studied animals with decomposition code 2. They presented high $\left(7^{*}\right)$ and very high (9) gas score. All deep divers with decomposition code 3 presented bubbles, most of them with values around or slightly higher than gas score 5 . Deep divers with decomposition code 4 had a gas score ranging from 7 to 10 , while those with decomposition code 5 had a gas score of 9 or 10 (Figure 5).

\section{GAS COMPOSITION}

\section{Intravascular bubbles of non-deep divers}

The main gas compound in intravascular bubbles recovered from non-deep divers in a fresh status or with incipient autolysis (codes 2 and 3) was nitrogen. Hydrogen was found in some samples of these animals (in one animal with decomposition code 2 and in two animals with decomposition code 3), especially in the mesenteric veins. When hydrogen was not present, nitrogen concentrations were between 70 and $90 \%$. On the other hand, samples from more decomposed animals (codes 4 and 5) consisted of high levels of $\mathrm{CO}_{2}(>30 \%)$ together with some hydrogen and/or nitrogen (Figure 6). In some cases, the sample was $100 \% \mathrm{CO}_{2}$.

\section{INTRAVASCULAR BUBBLES OF DEEP DIVERS Kogiidae}

Only four Kogia sp. individuals were studied. In addition they presented low gas scores, therefore few gas samples could be obtained. Gas samples were mainly composed of nitrogen (70$90 \%$ ) although hydrogen appeared with decomposition code 4 (Figure 7).

\section{Physeteridae}

In sperm whales, gas composition from fresh animals had consistently high nitrogen content (around 70\%). This gas composition changed dramatically with incipient autolysis. Gas composition from more decomposed animals consisted of a mixture of hydrogen, $\mathrm{CO}_{2}$, and nitrogen. Oxygen was only present in the three animals that stranded alive in the coast of Italy (Bernaldo de Quirós et al., 2011; Mazzariol et al., 2011; Figure 8).

\section{Globicephala}

Fresh pilot whales presented none or few bubbles; therefore only one sample from a fresh animal could be obtained. This sample was composed of a high concentration of nitrogen (74\%) together with oxygen and $\mathrm{CO}_{2}$. Samples from animals with incipient autolysis varied in composition. There were some intravascular bubbles with high nitrogen content although hydrogen was already present. The rest of the bubbles were composed of a mixture of $\mathrm{CO}_{2}$, hydrogen, and nitrogen in similar concentrations. In more decomposed animals, nitrogen levels decreased further, and the

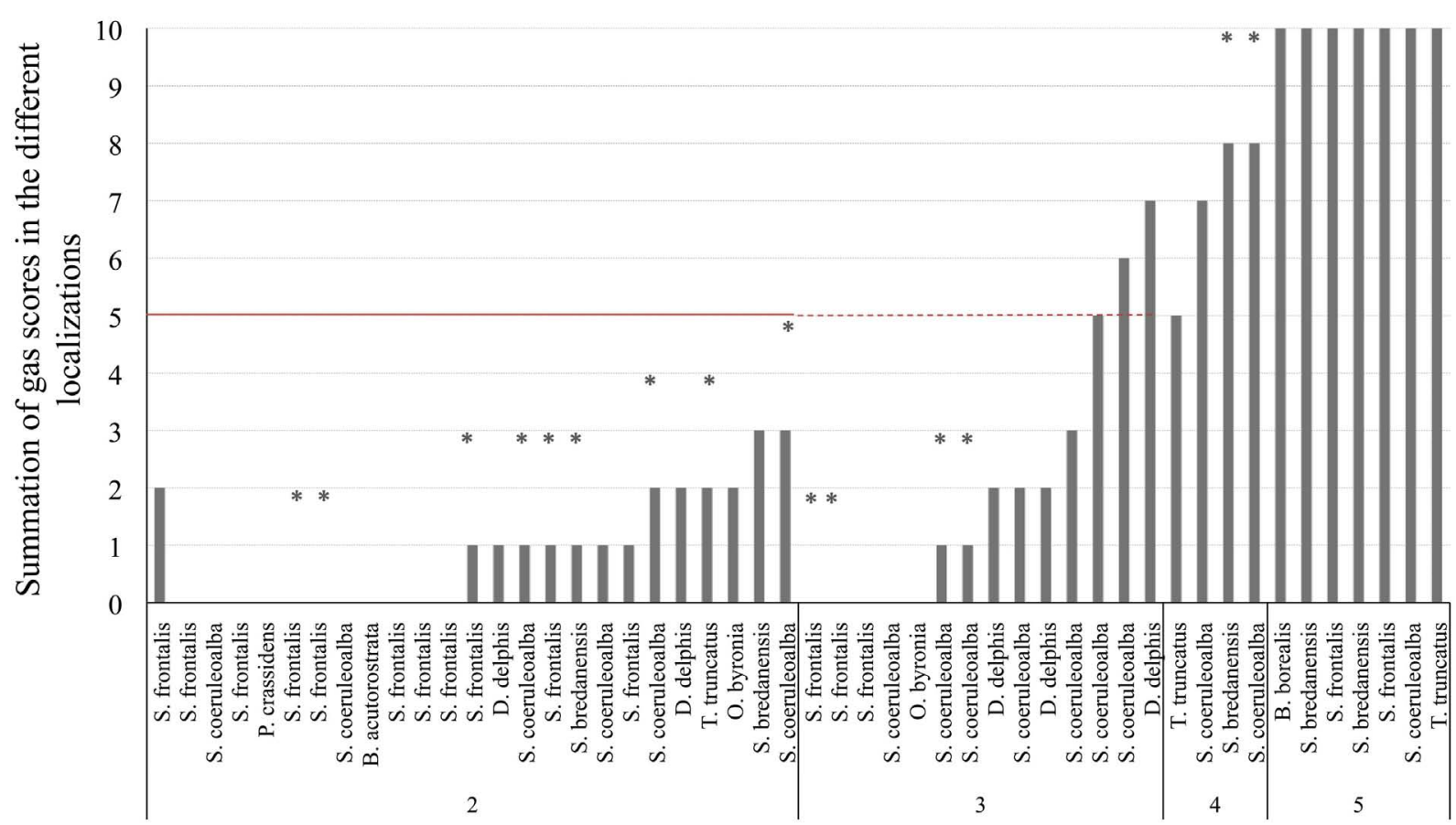

Decomposition code

FIGURE 4 | Total gas score (summation of gas scores in the different localizations) for each animal (non-deep divers). Asterisks represent the maximum potential summation gas score for a given animal, on which one localization was not adequately observed for bubbles. The red line is presented at half of the total gas score (5 of 10 ) in order to better illustrate the total gas scores of animals that fall above and bellow the medium. 


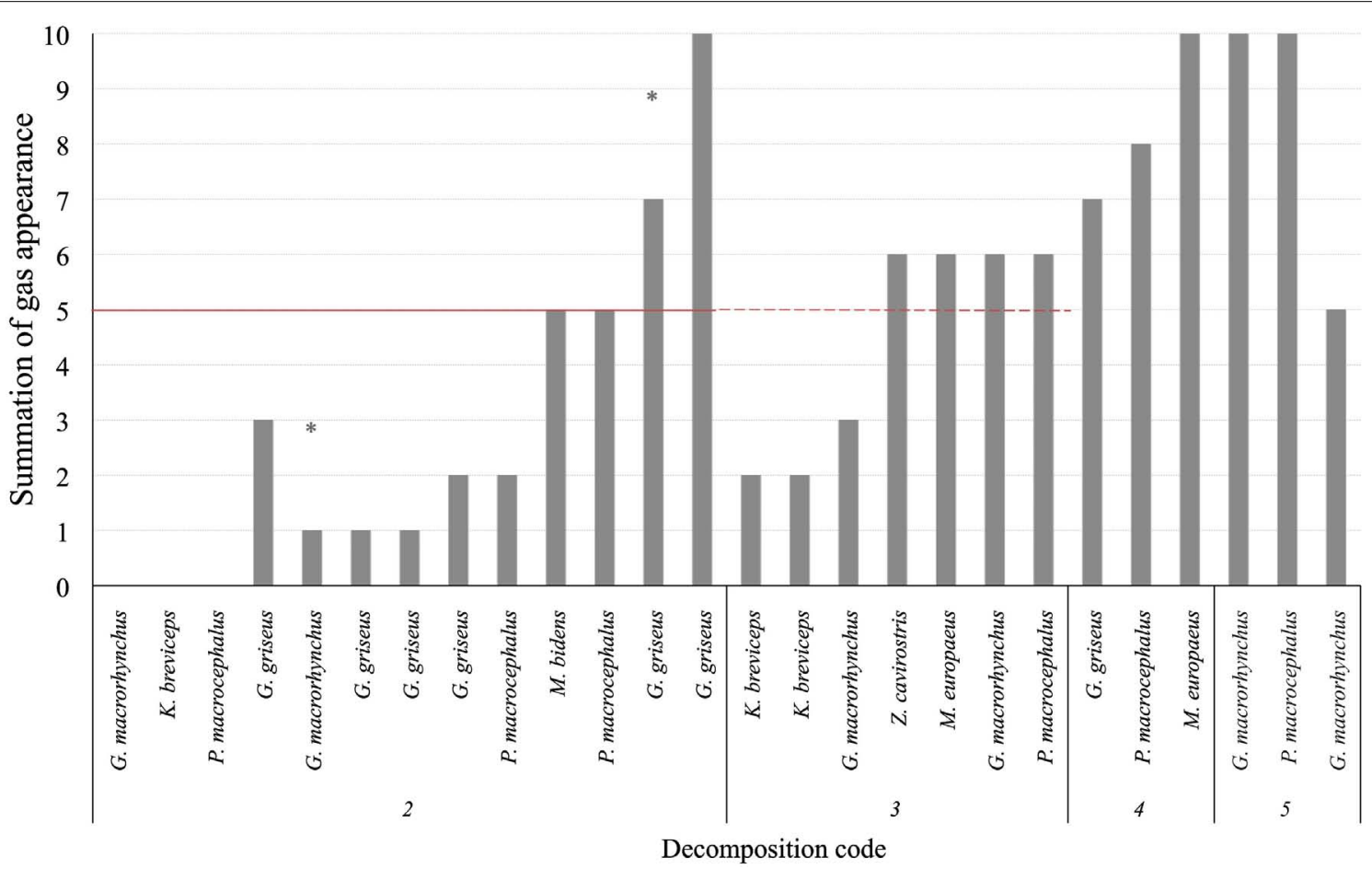

FIGURE 5 | Total gas score (summation of gas scores in the different localizations) for each animal (deep divers). Asterisks represent the maximum potential summation gas score for a given animal, on which one localization was not adequately observed for bubbles. The red line is presented at half of the total gas score ( 5 of 10 ) in order to better illustrate the total gas scores of animals that fall above and bellow the medium. gas was composed of a mixture of $\mathrm{CO}_{2}$ and hydrogen; $\mathrm{CO}_{2}$ having the highest concentration with nitrogen having concentrations lower than $30 \%$. In the samples from the most decomposed animals, nitrogen was no longer present. Intravascular bubbles were composed of a mixture of $\mathrm{CO}_{2}$ and hydrogen with similar concentrations, although $\mathrm{CO}_{2}$ content was always slightly higher than hydrogen. In summary, a clear difference was found in gas composition of bubbles in animals with different decomposition codes (Figure 9).

\section{Grampus}

Samples from fresh animals were composed of nitrogen, $\mathrm{CO}_{2}$, and in most cases some oxygen. They were composed of $76 \pm 7 \%$ of nitrogen and $15 \pm 9 \%$ of $\mathrm{CO}_{2}$, with the exception of "CET 483 " where higher $\mathrm{CO}_{2}$ concentrations were found (40-60\%). All these samples were clearly different from samples obtained from a more decomposed animal (with decomposition code 4) whose samples were mainly composed of $\mathrm{CO}_{2}$ and hydrogen (Figure 10).

\section{Ziphiidae}

Only one sample was successfully analyzed from a fresh animal. It was composed of high nitrogen content $(81 \%)$ and $\mathrm{CO}_{2}$. Gas composition from more decomposed animals was highly variable, with no clear trend along decomposition codes. Hydrogen was always present except for two samples from "CET 547" with decomposition code 4 . In this same animal there were three more samples with low hydrogen concentration (below 15\%). With the exception of these samples, nitrogen was always lower than $60 \%$ in the more decomposed animals. Samples were a mixture of $\mathrm{CO}_{2}$, nitrogen, and hydrogen. In some samples nitrogen was absent and bubbles were composed of $\mathrm{CO}_{2}$ and hydrogen exclusively (Figure 11).

\section{INTESTINAL GAS}

Gas composition from the intestines was highly variable with no trend with PM time. Nitrogen was found in high concentrations (higher than $60 \%$ ) in $21 \%$ of the samples. However, nitrogen was found in very low concentrations in the rest of the samples. In $40 \%$ of the samples, nitrogen was not present. In most of the samples $(67 \%), \mathrm{CO}_{2}$ was the major compound reaching values as high as $100 \%$. Hydrogen was very frequently found in the intestine (in $64 \%$ of the samples). Therefore most of the samples were a mixture of high $\mathrm{CO}_{2}$ levels with hydrogen and some, if any, nitrogen. Methane was only detected in Kogiidae and Physeteridae.

\section{SUBCAPSULAR EMPHYSEMA}

Subcapsular gas was composed of around $80 \%$ of nitrogen and $20 \%$ of $\mathrm{CO}_{2}$ in the fresh animals studied (a Risso's dolphin and a sea lion), except from one sample recovered from the peri-renal area of a common dolphin (CET 517). Gas composition of subcapsular samples from the fresh animals was clearly different from those of more decomposed animals, which mainly consist on $\mathrm{CO}_{2}$ and hydrogen. Nitrogen was lower than $30 \%$ when present. Nitrogen was found in high concentrations in only one sample from the most decomposed animals. This sample also presented the highest concentration of oxygen (15\% compared to a maximum of $4 \%$ in the rest of the samples; Figure 12). 


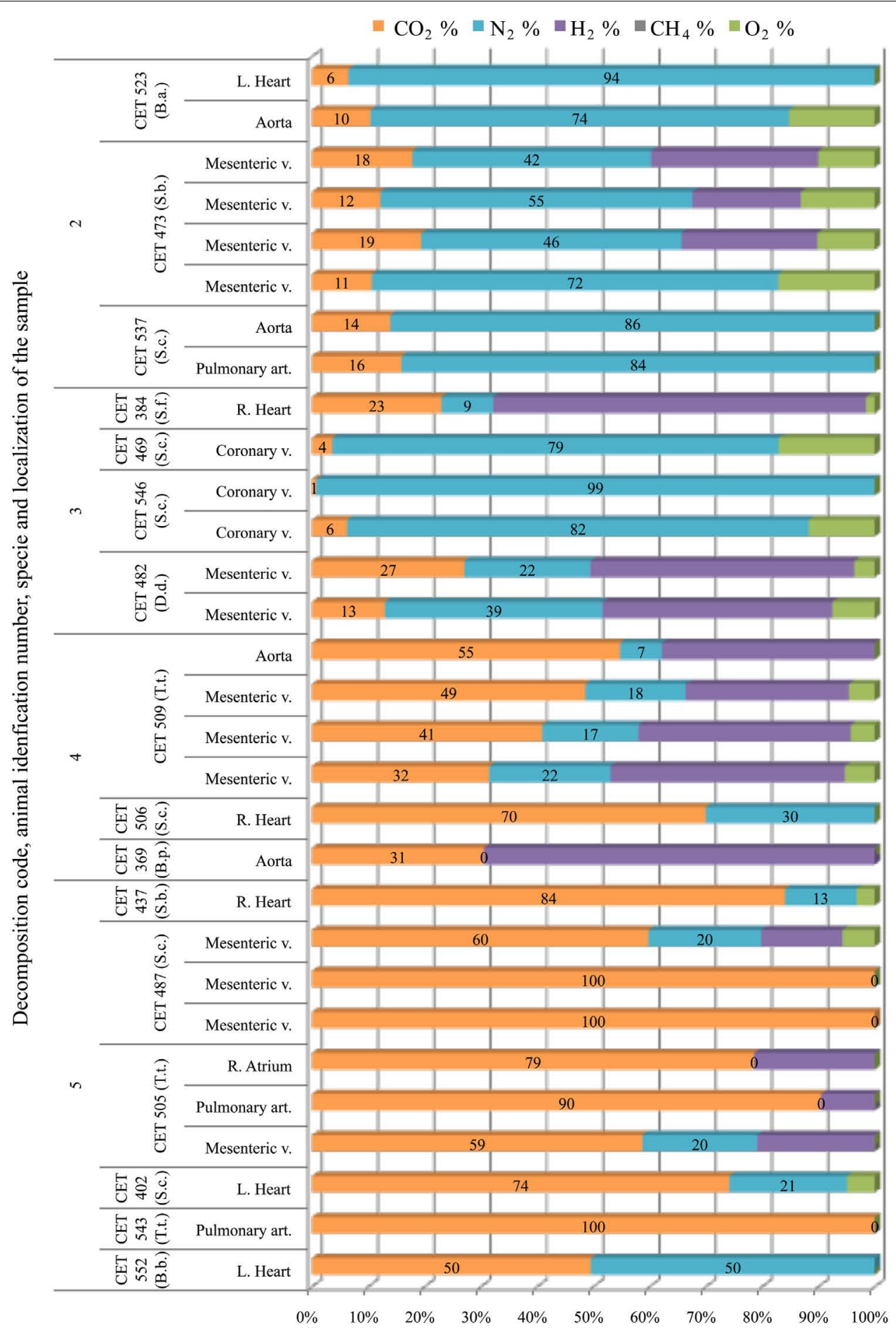

FIGURE 6 | Intravascular bubble's gas composition sampled form different non-deep diving species (B.a., Balaenoptera

acutorostrata; S.b., Steno bredanensis; S.c., Stenella coeruleoalba; S.f., Stenella frontalis; D.d., Delphinus delphis; T.t., Tursiops truncatus; B.p., Balaenoptera physalus; B.b., Balaenoptera borealis), in different tissues and decomposition codes, illustrating the contribution of each gas to the total amount in percentage $\mu \mathrm{mol}$.

\section{GAS FROM THE PTERYGOIDAL SINUSES}

Gas composition from the sinuses remained constant for longer PM time compared to gas recovered from other tissues. Nitrogen was always the major compound (58-87\%) until decomposition code 4 was reached. Within these decomposition codes, $\mathrm{CO}_{2}$ was present in concentrations ranging from 10 to $36 \%$. After 


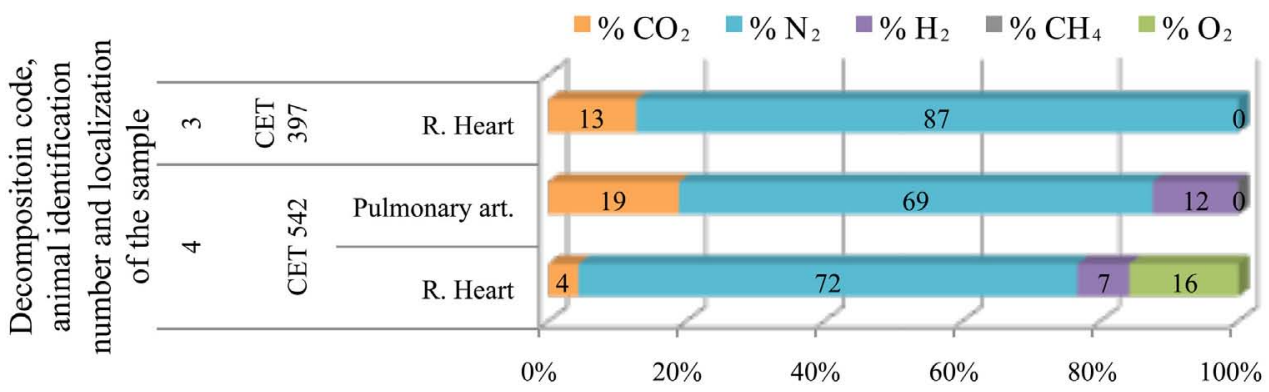

FIGURE 7 | Intravascular bubble's gas composition of deep diving animals belonging to Kogiidae family in different tissues and decomposition codes, illustrating the contribution of each gas to the total amount in percentage $\mu \mathrm{mol}$.

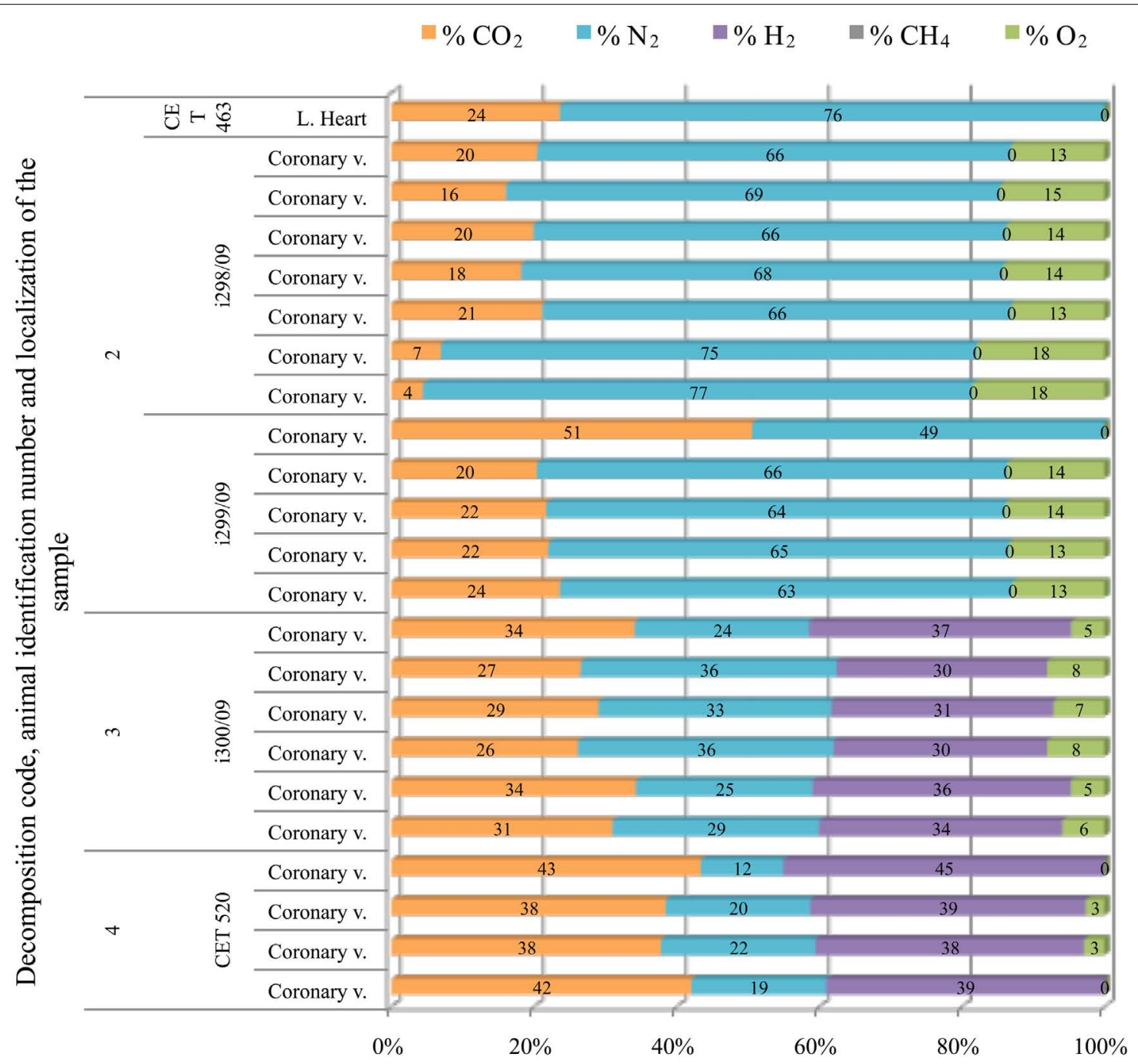

FIGURE 8 | Intravascular bubble's gas composition of deep diving animals belonging to Physeteridae family in different tissues and decomposition codes, illustrating the contribution of each gas to the total amount in percentage $\mu \mathrm{mol}$.

decomposition code $4, \mathrm{CO}_{2}$ increased devaluating nitrogen presence. There were two samples with atmospheric-air like composition (CET 512 and CET 504) (Figure 13).

\section{DISCUSSION}

This is the first comprehensive study of prevalence, amount (gas score), distribution, and composition of bubbles found in stranded 


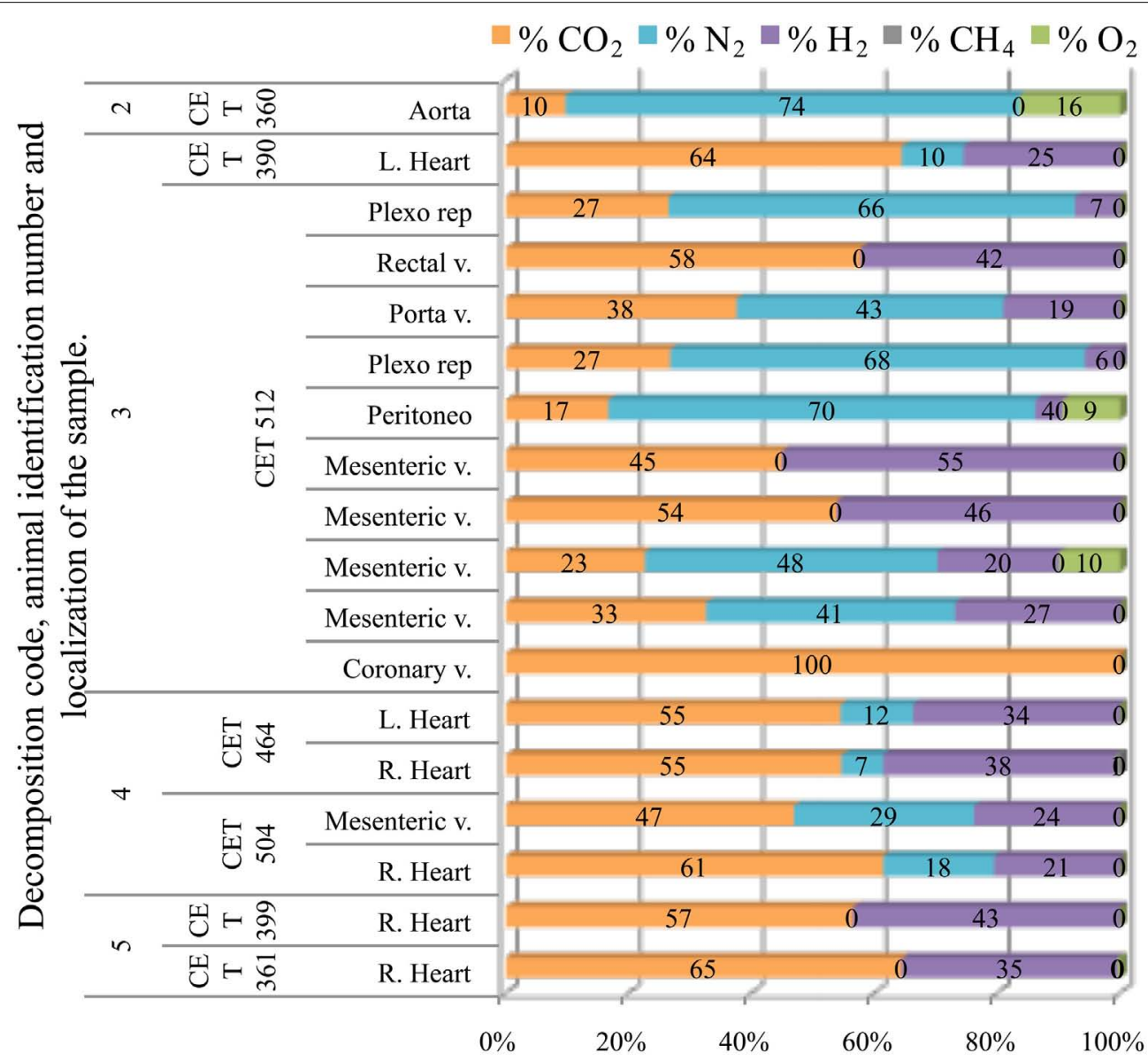

FIGURE 9 | Intravascular bubble's gas composition of deep diving animals belonging to Globicephala macrorhynchus specie in different tissues and decomposition codes, illustrating the contribution of each gas to the total amount in percentage $\mu \mathrm{mol}$.

cetaceans. The animals included in the study presented different decomposition codes allowing us to study putrefaction gases that may mask a decompression-induced gas phase. In addition, the high number of animals (83) and species included in the study (18) enabled us to relate the results with the diving behavior of the animals. This study demonstrates the utility of scoring and analyzing the gas in stranded marine mammals, especially in fresh animals, encouraging the performance of the necropsy as soon after death as possible.

\section{BUBBLE PREVALENCE AND ABUNDANCE}

Fifty-one out of 88 stranded animals presented macroscopic bubbles during the necropsy. This represents $58 \%$ of the animals that were studied indicating that the presence of gas bubbles within the cardiovascular system in stranded cetaceans is a common gross finding during necropsy.

In forensic human pathology the presence of intravascular gas in carcasses decomposing under different environmental conditions is well known and widely reported (Knight, 1996). Indeed, bubbles were found in all the studied animals with decomposition code 4 and 5. Putrefaction is a continual process of gradual decay and disorganization of organic tissues and structures after death that results in the production of liquids, simple molecules, and gases (intravascular gas and/or putrefactive emphysema; Vass et al., 2002; Lerner and Lerner, 2006). However, it is very unusual to find gas bubbles within the cardiovascular system in fresh necropsied domestic animals or humans (King et al., 1989; Knight, 1996). Therefore, the most interesting data are those recorded from fresh animals. Our results demonstrated that it is not uncommon to find intravascular bubbles in fresh cetaceans. Thirty-three percent of our fresh animals presented intravascular bubbles to some extent, but only two animals presented high gas score. Recent studies have demonstrated that large amounts of intravascular bubbles found within a few hours PM are not due to putrefaction processes (Bernaldo de Quirós, 2011). Indeed, these animals were the only ones diagnosed with gas embolism according to the pathological studies carried out by the ULPGC. Therefore amount of intravascular bubbles is more important than the mere presence of bubbles from a pathological point of view in stranded cetaceans, and the gas score is also an efficient tool to distinguish between gas embolism and putrefaction gases in stranded cetaceans. Although we used a simple gas scoring technique with a scale from 0 to 10 because the study was done retrospectively, we encourage using a larger gas score scale (0-27) described by Bernaldo de Quirós (2011). This 


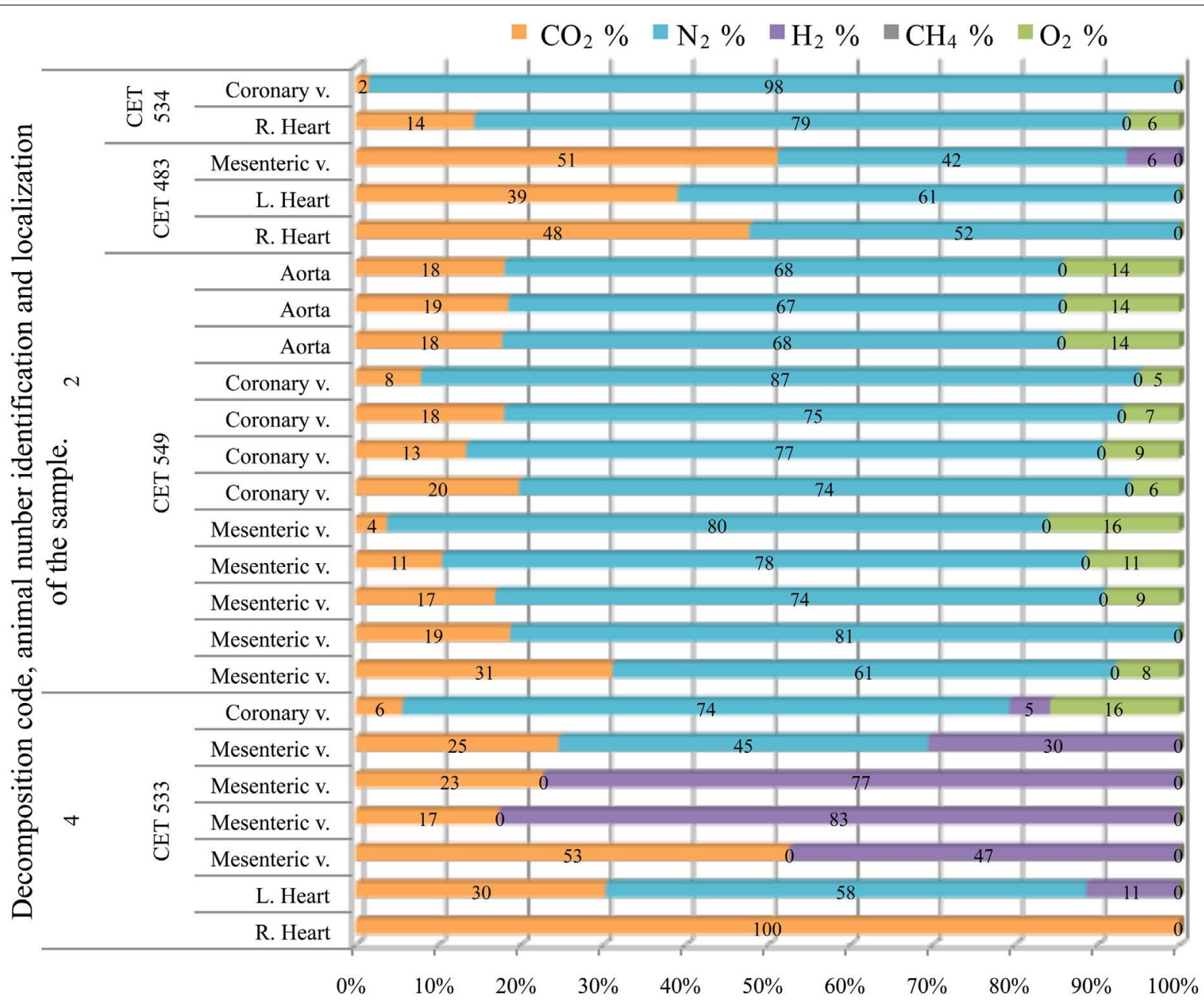

FIGURE 10 | Intravascular bubble's gas composition of deep diving animals belonging to Grampus griseus specie in different tissues and decomposition codes, illustrating the contribution of each gas to the total amount in percentage $\mu \mathrm{mol}$.

gas score has a grading scoring of $0-6$ for the different vascular localizations $(n=4)$ and a $0-3$ grading scoring for subcapsular gas (0-3). Therefore, total gas score in each animal ranged from 0 to 27 . A larger scale highlights better the possible differences in gas score along decomposition codes.

Subcapsular emphysema in the peri-renal area has been described in 22 of 22 alive stranded animals using B-mode ultrasound (Dennison et al., 2012). In our study, we found it in 20 out of 39 fresh animals. Although the prevalence is smaller in our study, it still suggests that subcapsular emphysema is a common finding in dead stranded cetaceans. However, we could not find a clear relationship between subcapsular emphysema and intravascular bubbles. There is a $60 \%$ chance that a fresh animal with intravascular bubbles presents subcapsular emphysema, but $60 \%$ of the fresh animals with subcapsular emphysema showed no intravascular bubbles. Therefore, intravascular bubbles can occur without simultaneous subcapsular emphysema and vice versa.

An interesting result from our data was that intravascular bubbles were more frequently found $(P=0.006)$ and in higher quantities in deep divers than in non-deep divers regardless of decomposition code. The higher prevalence of intravascular bubbles related to the diving behavior of the species, together with the fact that finding bubbles in necropsied domestic animals or humans is very unusual and mostly linked to iatrogenic air embolism or diving fatalities (Knight, 1996; Muth and Shank, 2000), suggest that the most parsimonious explanation for the presence of small quantities of intravascular bubbles in fresh stranded cetaceans would be diving physiology related (Tikuisis and Gerth, 2003). Thus our results further suggest that deep divers might be at a higher risk from decompression.

\section{GAS COMPOSITION}

Intravascular bubbles and subcapsular emphysema of fresh marine mammals (decomposition code 2) showed high concentrations of nitrogen $(>70 \%)$ and values of $\mathrm{CO}_{2}$ around $20 \%$. Similar results were obtained in animal models exposed to air embolism or compression and decompression using the same methodology (Bernaldo de Quirós, 2011). Furthermore, these values are in accordance to what has been reported in cases of air embolism and/or DCS in humans and laboratory animals 


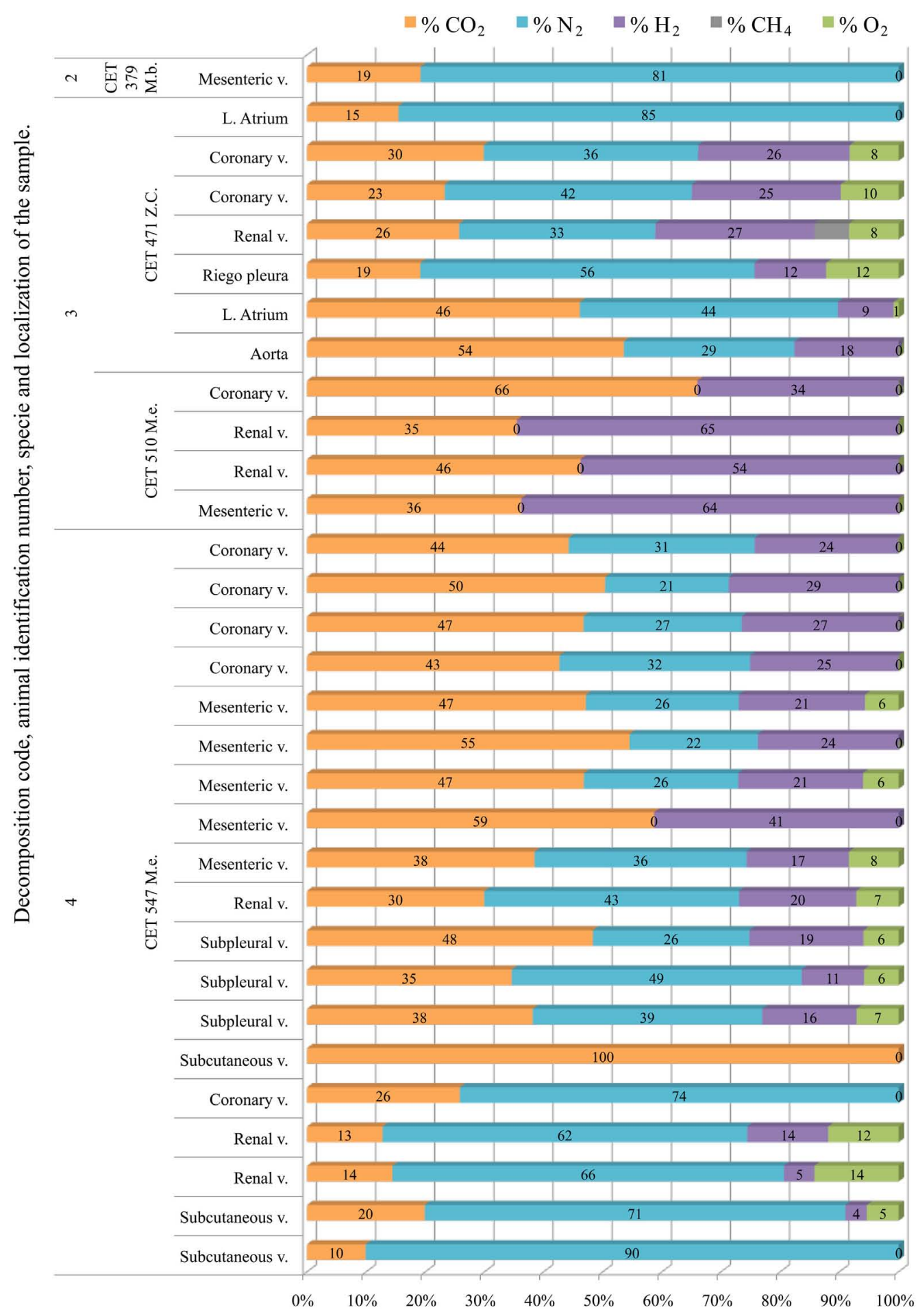

FIGURE 11 | Intravascular bubble's gas composition of deep diving animals belonging to Ziphiidae (M.b., Mesoplodon bidens; Z.c., Ziphius cavirostris; M.e., Mesoplodon europaeus) family in different tissues and decomposition codes, illustrating the contribution of each gas to the total amount in percentage $\mu \mathrm{mol}$.
(Bert, 1878; Armstrong, 1939; Pierucci and Gherson, 1968; SmithSivertsen, 1976; Ishiyama, 1983; Bajanowski et al., 1998; Bernaldo de Quirós, 2011). In addition, gas from pterygoideal sinuses showed high concentrations of nitrogen in animals with decomposition codes 2 and 3. This was an additional finding that needs further investigation (Figure 13). 


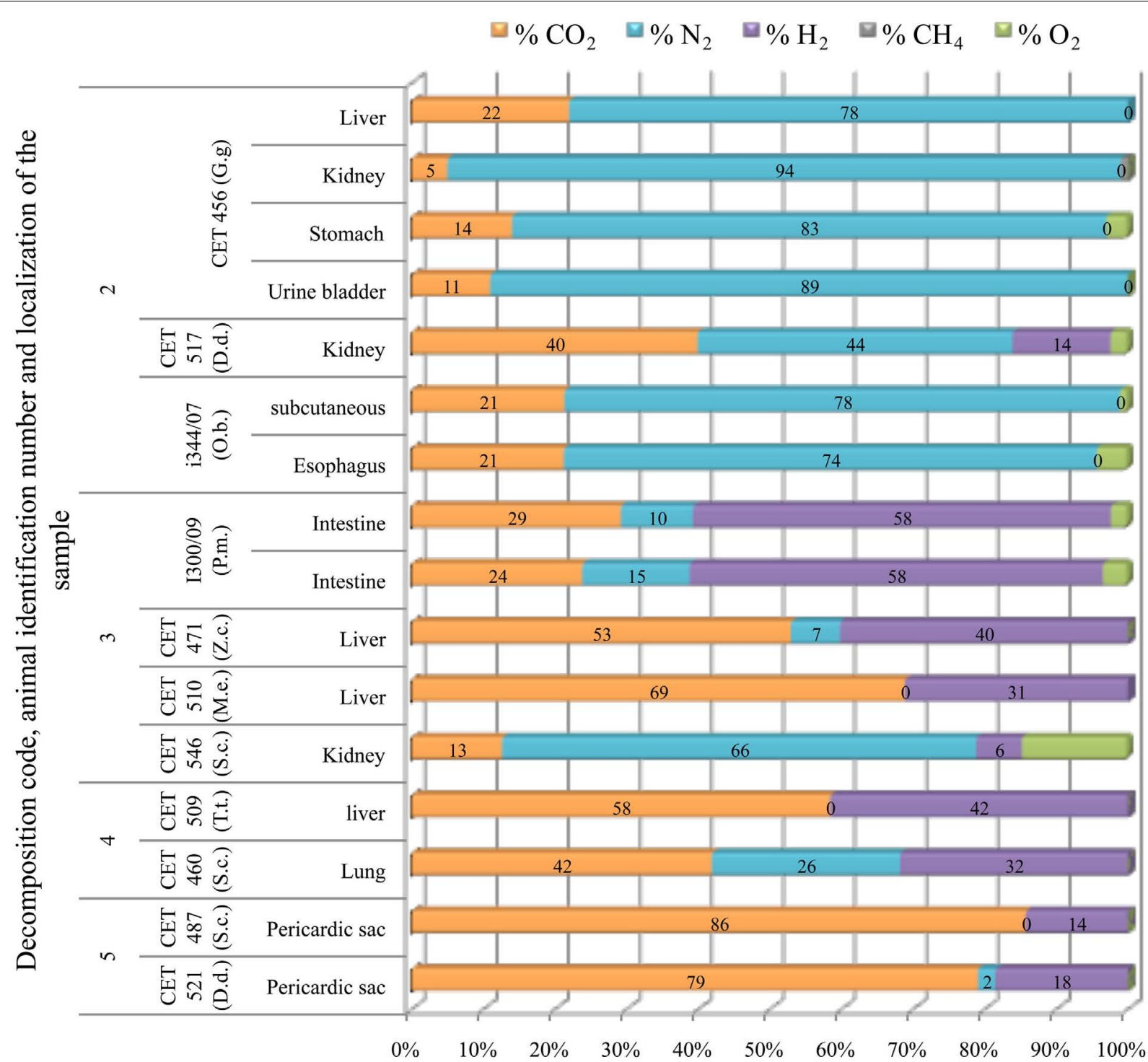

FIGURE 12 | Subcapsular gas (emphysema) composition found in different tissues from deep diving (G.g., Grampus griseus; D.d., P.m., Physeter macrocephalus; Z.c., Ziphius cavirostris; M.e., Mesoplodon europaeus) and shallow diving animals (D.d.,
Delphinus delphis; O.b., Otaria byronia; S.c., Stenella coeruleoalba; T.t., Tursiops truncatus) with different decomposition codes, illustrating the contribution of each gas to the total amount in percentage $\mu \mathrm{mol}$.
Hydrogen, which is a putrefaction indicator (Pierucci and Gherson, 1969), was mostly found after decomposition code 3 in gas collected from the different localizations (intravascularly, subcapsularly, or in the pterygoideal sinuses). Animals with incipient autolysis (decomposition code 3 ), had gas samples that varied from typical gas embolism composition to putrefaction gases (Pierucci and Gherson, 1968, 1969). Samples from animals with decomposition code 4 and 5 always presented high $\mathrm{CO}_{2}$ concentrations together with hydrogen in most of the cases and low concentration of nitrogen (mostly lower than 40\%) if present. In a few decomposed samples, small quantities of oxygen were also detected. This gas composition was very similar to the gas composition of the subcapsular emphysema found in very decomposed animals and completely different from gas composition of intravascular bubbles and subcapsular emphysema in fresh animals.

These data show that detection of hydrogen and/or very high levels of $\mathrm{CO}_{2}$ are "signal" gases indicative of putrefaction, while nitrogen decreases progressively until disappearing (not detected chromatographically) in carcasses with the highest decomposition code (code 5). Similar results have been described in humans and laboratory animals (Pierucci and Gherson, 1968, 1969; Keil et al., 1980; Bajanowski et al., 1998). In this sense, we can state that hydrogen in stranded cetaceans is also a key putrefaction marker with one exception that will be discussed later. In some cases, we have found one sample's composition to be clearly different from the rest of the samples, presenting significantly higher nitrogen and oxygen content. Thus, we have considered as a first option, a 


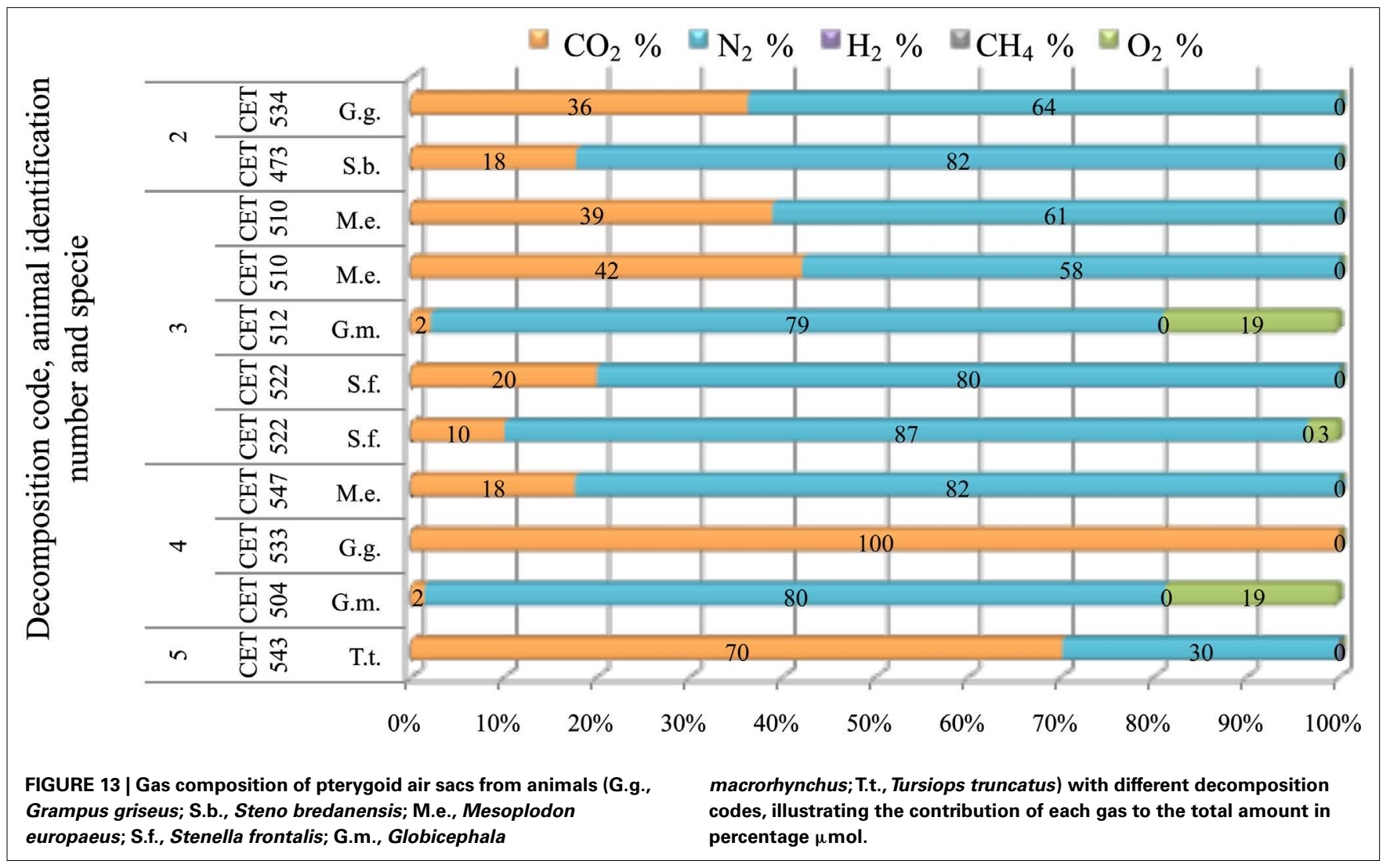

likely contamination of atmospheric-air during sampling (see as an example the sample from CET 546 in Figure 12). The exception previously mentioned, was a Steno bredanensis (CET 473) with decomposition code 2 that presented hydrogen in the mesenteric veins. Here, it is important to remember that these are stranded animals, and in most of the cases sick animals. Therefore these gas results should be considered together with the individual diagnostic analysis (including pathology, microbiology, toxicology, etc.). Speculatively, we have considered acute gastrointestinal disease as a primary source of hydrogen or due to overlapping with other pathogenic processes, although further research is needed in order to confirm this hypothesis.

One of the most interesting and unexpected results was $\mathrm{CO}_{2}$ concentrations of around $40-50 \%$ in the animal with the second highest gas score for fresh animals and diagnosed with gas embolism by the ULPGC (CET 483). This gas composition is not in accordance with traditional DCS theories or some of the empirical values reported for DCS (Bert, 1878; Smith-Sivertsen, 1976; Ishiyama, 1983; Tikuisis and Gerth, 2003). However Armstrong (1939) reported values of $30 \%$ of $\mathrm{CO}_{2}$ in decompressed goats, and Bernaldo de Quirós (2011) has recently reported very similar $\mathrm{CO}_{2}$ concentrations to our results in rabbits.

In addition there are several empirical and physical models suggesting an important role of $\mathrm{CO}_{2}$ in bubble formation: (i) there is a higher prevalence of elevated $\mathrm{CO}_{2}$ in bends following dives using compressed air (Behnke, 1951), (ii) a statistically significant increase in DCS risk in rats breathing elevated levels of $\mathrm{CO}_{2}$ in either $\mathrm{He}-\mathrm{O}_{2}$, or $\mathrm{N}_{2}-\mathrm{O}_{2}$ mixtures during the hyperbaric exposure has been reported (Berghage et al., 1978), (iii) bubbles moving vertically through different water layers alternately saturated with air or $\mathrm{CO}_{2}$, increase in size in the $\mathrm{CO}_{2}$ saturated water and decreasing in the air-saturated layer (Harvey, 1945), (iv) bubbles formed with less mechanical agitation and grew at a faster rate in decompressed tubes filled with water saturated of $\mathrm{CO}_{2}$ rather than nitrogen (Harris et al., 1945). All these findings, suggest that $\mathrm{CO}_{2}$ might play an important role in bubble formation due to the high diffusivity of this gas. If this is the case, prolonged dives where $\mathrm{CO}_{2}$ will build up might pose an additional risk to animals with nitrogen saturation.

Theoretical studies have predicted BWs end-dive nitrogen levels that would cause a significant proportion of DCS cases in land mammals (Houser et al., 2001; Zimmer and Tyack, 2007; Hooker et al., 2009). In addition BWs have both the deepest $(3120 \mathrm{~m})$ and longest $(137 \mathrm{~min})$ dives ever recorded from an air-breathing mammal (Schorr et al., 2011). Furthermore, BWs exposed to midfrequency sonar playback have reacted with unusual longer and slower ascent dives (Tyack et al., 2011). All BWs included in our study presented a minimum gas score of 5 , this was not found in the other studied sub groups. Although more fresh animals should be studied in order to make conclusions, our results suggest that BWs might be the most sensitive species to bubble formation. Future theoretical studies should consider $\mathrm{CO}_{2}$ accumulation in addition to nitrogen saturation, and its possible role in bubble formation.

We have shown that gas analysis may be a valid a technique to differentiate between gas embolism and putrefaction gases in stranded cetaceans. Therefore we encourage gas analysis. To try to avoid putrefaction-masking gases, necropsy, and gas sampling 
must be performed as soon as possible, before $24 \mathrm{~h} \mathrm{PM}$ is recommended but preferably within $12 \mathrm{~h}$ PM. However, if gas analyses are not possible due to logistics, we strongly recommend doing the gas scoring, which is of no additional cost.

\section{SOURCE OF BUBBLES}

In summary, intravascular bubbles and subcapsular emphysema are a common finding during necropsies of stranded marine mammals, although they are present in low quantities (low gas score) and with a gas composition of around $70-80 \%$ of nitrogen and $20-30 \%$ of $\mathrm{CO}_{2}$. They are more frequently found $(P=0.006)$ and in higher quantities in deep divers vs. non-deep divers. They have higher prevalence in active stranded animals, although they are also present in passive stranded animals. Based on gas composition and in the highest prevalence of bubbles in deep divers, the most likely source of these bubbles is decompression-related.

In air-breathing animals, nitrogen can build up in tissues and formed bubbles. Although they only have a finite amount of air in their lungs available for nitrogen diffusion, $\mathrm{PN}_{2}$ in the alveoli increases with compression of the thorax as the pressure increases. This results in a net exchange of nitrogen across the alveolar membrane and it is either taken up or removed by the blood and tissues depending on the partial pressure gradient. During ascent, nitrogen diffusion from tissues to blood and alveolus is slower, and if the surface interval is too short, not all of the nitrogen that has been taken up is removed. This may result in nitrogen build up in tissues during repeated dives (Ferrigno and Lundgren, 2003). When the sum of the dissolved gas tensions (oxygen, $\mathrm{CO}_{2}$, nitrogen, helium) and water vapor exceeds the local absolute pressure, a state known as supersaturation, bubbles may form due to gas phase separation (Hamilton and Thalmann, 2003; Vann et al., 2011). Bubbles can form without negatively impacting a diving animal, but bubbles can have mechanical, embolic, and biochemical manifestations ranging from trivial to fatal (Vann et al., 2011). They are generally considered a pivotal event in the occurrence of DCS (Francis and Simon, 2003).

Decompression bubble formation may still occur even after death if the animal dies at depth and is later depressurized, a phenomenon known as post mortem off gassing (Brown et al., 1978; Lawrence, 1997; Cole et al., 2006; Lawrence and Cooke, 2006; Wheen and Williams, 2009). Post mortem off gassing has been proposed for explaining the existence of bubbles in marine mammals trapped in fishing nets (Moore et al., 2009). These animals died at depth and were later hauled out. Our studied animals are stranded marine mammals, which presumably have not died at depth. Thus, post mortem off gassing is ruled out as a plausible mechanism. The stated absence of bubbles in stranded animals in the Moore et al. study probably reflects a relative, rather than absolute absence, with bubble quantity being far more obvious in the animals drowned at depth that off-gassed post mortem. These authors probably failed to record the low prevalence of bubbles commonly seen in stranded animals in the current study (Michael Moore, personal communication). It is interesting that the Moore et al. findings likely reflect a routine supersaturation state in foraging, diving marine mammals. Analysis of the gas bubble composition of drowned bycatch would test this hypothesis.
The most likely explanation for the observed gas composition in the freshly dead animals is that bubbles were in vivo or peri mortem formed from supersaturated tissues by physiological off gassing. Indeed, a recent study has shown that intravascular bubbles and peri-renal subcapsular emphysema occur in live marine mammals and without clinical consequences (Dennison et al., 2012). The stranding itself has been proposed as a causal mechanism for bubble formation in marine mammals (Houser et al., 2010; Dennison et al., 2012). According to this hypothesis, a fast stranding will result in the inability to recompress resulting in problematic supersaturation of the tissues. In addition, as a consequence of the stranding, there would be tissues of reduced perfusion and blood pooling that would continue to off-gas, but because the vascular flow to the lung is supposed to be compromised, nitrogen elimination would not be as effective and autochthonous bubble formation would increase (Houser et al., 2010).

Another plausible stranding mechanism related would be tribonucleation. Tribonucleation occurs when two surfaces in intimate contact but separated by a viscous liquid film are suddenly separated in an abrupt way. Then, the viscosity will avoid sudden filling and cavities, which will be filled by diffusing gases, can occur (Banks and Mill, 1953; Hayward, 1967; Campbell, 1968; Ikels, 1970; Blatteau et al., 2006). This phenomenon has been proposed to happen with movements, exercise (McDonough and Hemmingsen, 1984a,b, 1985a,b), within the joints (Fick, 1911), or in the heart valves (Hennessy, 1989). The agonal actions of the beached animals have been proposed to promote bubble formation (Houser et al., 2010).

We have found intravascular bubbles in 3 out of 15 of the animals that stranded passively, where reduced perfusion and tribonucleation are not expected. Regardless of the low number of passive strandings studied, our results support the idea that bubbles can occur independently to the stranding, as reported in three BWs (one fresh, one partially autolytic, and an autolytic animal) which were recovered floating in the atypical mass stranding event of the Canary Islands in 2002 (Fernandez et al., 2005). However, since we have found a higher prevalence of bubbles in actively stranded animals (although the difference was non-statistically significant), we suggest that stranding is not a necessary factor but a contributing factor in bubble formation.

More recently, Houser et al. (2010) and Dennison et al. (2012) hypothesized that the abnormal behavior of moribund cetaceans that might spend a period of time at sea with reduced depth and repetitiveness, may allow them to wash out nitrogen prior to stranding. Few (Dennison et al., 2012) or no (Houser et al., 2010) empirical data were presented to support this suggestion. Our study animals are mostly single stranded specimens, affected by different pathologies (Table 1). According to the mentioned hypothesis, it is presumed that our case studies have washed out their nitrogen prior to stranding. Our results do not support this hypothesis; intravascular bubbles were found in $57 \%$ of the fresh deep diving animals and in $20 \%$ of the non-deep diving animals, and they were mainly composed of nitrogen (70-80\%). Dennison et al. (2012) further hypothesize that the prevalence of bubbles will be less in most single stranded than mass stranded animals, if they were diving less over an extended period. Since our study cases are mostly single stranded animals, we could not test this 
hypothesis. Further studies are needed to confirm whether mass stranded animals have higher prevalence of bubbles compared to single-stranded animals.

If bubbles are not a consequence of the stranding, and since no embolic related lesions were found in the pathological study, it is reasonable to consider as a hypothesis that this small amount of bubbles composed of nitrogen found in fresh stranded animals, were silent bubbles. The existence of potentially asymptomatically bubbles in marine mammals has been reported before (Dennison et al., 2012). However, we studied dead animals where symptoms could not be evaluated, therefore our results are indicative but not conclusive by itself of the existence of silent bubbles in marine mammals. A recent review of evidences for gas bubble incidence in marine mammals concluded that they may deal with bubbles on a more regular basis than previously thought (Hooker et al., 2012) and suggested that our view of marine mammal adaptations should therefore change from one of simply minimizing nitrogen loading to one of management of the nitrogen load. Our study further supports the hypothesis that decompression-induced bubbles are relatively common but that marine mammals have unknown adaptations allowing them to tolerate these under natural conditions. It is important to remember that our case studies have only few bubbles and died from numerous pathological reasons different from gas embolism. Only two animals, showing a lot of bubbles widely dispersed and with no other pathological signs, were diagnosed with massive gas embolism.

Further research is needed in order to clarify questions that remain unanswered from this study. The clinical impact of subcapsular emphysema remains unclear from this study since gas composition indicates a plausible physiological decompressionrelated off gassing origin, but no clear relationship with intravascular bubbles was found. More studies are needed in order to better understand the formation of this gas and the plausible impact that might have on the health status of the animals.

\section{REFERENCES}

Aguilar de Soto, N. (2006). Acoustic and Diving Behaviour of the Short Finned Pilot Whale (Globicephala macrorhynchus) and Blainville's Beaked Whale (Mesoplodon densirostris) in the Canary Islands. Implications of the Effects of Man-Made Noise and Boat Collisions. Doctoral thesis, La Laguna University, La Laguna.

Arbelo, M. (2007). Patología y causas de la muerte de los cetáceos varados en las Islas Canarias (1999-2005). Ph.D. Doctoral thesis, University of Las Palmas de Gran Canaria, Las Palmas de Gran Canaria.

Armstrong, H. G. (1939). Analysis of Gas Emboli. Engineering Section Memorandum Report EPX-17-54-653-8, Wright Field, OH.

Astruc, G., and Beaubrun, P. (2005). Do Mediterranean cetaceans diets overlap for the same resources? Eur. Res. Cet. 19, 81.
Bajanowski, T., Kohler, H., Duchesne, A., Koops, E., and Brinkmann, B. (1998). Proof of air embolism after exhumation. Int. J. Legal Med. 112, 2-7.

Banks, W. H., and Mill, C. C. (1953). Tacky adhesion - A preliminary study. J. Colloid Sci. 8, 137-147.

Behnke, A. R. (1951). "Decompression sickness following exposure to high pressures," in Decompression Sickness, ed. J. F. Fulton (Phyladelphia: Saunders), 53-89.

Belanger, L. F. (1940). A study of the histological structure of the respiratory portion of the lungs of aquatic mammals. Am. J. Anat. 67, 437-469.

Berghage, T. E., Keating, L. J., and Wooley, J. M. (1978). "Decompression sickness in rats and mice rapidly decompressed after breathing various concentrations of carbon dioxide," in Proceedings of the Sixth Underwater Physiology Symposium,

Comparison between single-active, single-passive, mass stranded, and by caught animals, might contribute to a better understanding of the causative factor of intravascular bubble formation as well as nitrogen supersaturation levels on these animals, and different species sensibilities (like deep divers vs. non-deep divers). These will provide new data that should be considered in future diving physiology models and studies.

In conclusion, this study has demonstrated that bubbles are a common finding in stranded cetaceans. The amount and composition of these bubbles in fresh animals suggests that these bubbles have formed from nitrogen-supersaturated tissues, most likely formed in vivo. This study has also demonstrated that these bubbles were more frequently found in deep divers indicating a higher risk of decompression to these species. Further research is needed in order to determine if there are any species-specific sensibilities to bubble formation as preliminary results point out, as well as the implications that $\mathrm{CO}_{2}$ accumulation along a dive might have for these animals from a diving physiology perspective. Finally, monitoring live non-deep diving and deep diving animals with an ultrasound might help to confirm the hypothesis deduced from our results.

\section{ACKNOWLEDGMENTS}

The authors would like to thank all colleagues from the University of Las Palmas de Gran Canaria (Spain) that contribute to this work and to the different stranding networks and governments: Canary Islands, United Kingdom, and Italy. This work was supported by the Spanish Ministry of Science and Innovation with two research projects: (AGL 2005-07947) and (CGL 2009/12663), as well as the Government of Canary Islands (DG Medio Natural). The Spanish Ministry of Education contributed with personal financial support (the University Professor Formation fellowship). The Woods Hole Oceanographic Institution Marine Mammal Centre and Wick and Sloan Simmons provided funding for the latest stage of this work.

ed. C. J. Lambertsen (Bethesda) 485-496.

Bernaldo de Quirós, Y. (2011). Methodology and Analysis of Gas Embolism: Experimental Models and Stranded Cetaceans. Ph.D. Doctoral thesis, University of Las Palmas de Gran Canaria, Las Palmas de Gran Canaria.

Bernaldo de Quirós, Y., GonzálezDíaz, Ó., Saavedra, P., Arbelo, M. Sierra, E., Sacchini, S., Jepson, P. D. Mazzariol, S., Di Guardo, G., and Fernández, A. (2011). Methodology for in situ gas sampling, transport and laboratory analysis of gases from stranded cetaceans. Sci. Rep. 1, 193.

Bert, P. (1878). La Pression Barometrique: Recherches de Physiologie Expérimentale. Paris: Masson.

Blatteau, J. E., Souraud, J. B., Gempp, E., and Boussuges, A. (2006). Gas nuclei, their origin, and their role in bubble formation.
Aviat. Space Environ. Med. 77, 1068-1076.

Bostrom, B. L., Fahlman, A., and Jones, D. R. (2008). Tracheal compression delays alveolar collapse during deep diving in marine mammals. Respir. Physiol. Neurobiol. 161, 298-305.

Brown, C. D., Kime, W., and Sherrer, E. L. (1978). Postmortem intra-vascular bubbling - decompression artifact. J. Forensic Sci. 23, 511-518.

Butler, P. J., and Jones, D. R. (1997). Physiology of diving of birds and mammals. Physiol. Rev. 77, 837-899.

Campbell, J. (1968). The tribonucleation of bubbles. J. Phys. D: Appl. Phys. 1, 1085-1088.

Cole, A. J., Griffiths, D., Lavender, S., Summers, P., and Rich, K. (2006). Relevance of postmortem radiology to the diagnosis of fatal cerebral gas embolism from compressed air diving. J. Clin. Pathol. 59, 489-491. 
Cox, T. M., Ragen, T. J., Read, A. J., Vos, E., Baird, R. W., Balcomb, K., Barlow, J., Caldwell, J. M., Cranford, T., Crum, L. A., D’Amico, A., D'Spain, G., Fernandez, A., Finneran, J. J., Gentry, R., Gerth, W. A., Gulland, F. M. D., Hildebrand, J., Houser, D., Hullar, T., Jepson, P. D., Ketten, D., Macleod, C. D., Miller, P., Moore, S., Mountain, D. C., Palka, D., Ponganis, P. J., Rommel, S., Rowles, T., Tyack, P. L., Wartzok, D., Gisiner, R., Mead, J., and Benner, L. (2006). Understanding the impacts of anthropogenic sound on beaked whales. J. Cetacean Res. Manag. 7, 117-187.

Denison, D. M., and Kooyman, G. L. (1973). Structure and function of small airways in pinniped and sea otter lungs. Respir. Physiol. 17, 1-10.

Dennison, S., Moore, M. J., Fahlman, A., Moore, K., Sharp, S., Harry, C. T., Hoppe, J., Niemeyer, M., Lentell, B., and Wells, R. S. (2012). Bubbles in live-stranded dolphins. Proc. R. Soc. B Biol. Sci. 279, 1396-1404.

Elsner, R. (1999). "Living in water: solutions to physiological problems," in Biology of Marine Mammals, eds J. E. III. Reynolds and S. Rommel (Washington, DC: Smithsonian Institution Press), 73-116.

Fahlman, A., Olszowka, A., Bostrom, B., and Jones, D. R. (2006). Deep diving mammals: dive behavior and circulatory adjustments contribute to bends avoidance. Respir. Physiol. Neurobiol. 153, 66-77.

Falke, K. J., Hill, R. D., Qvist, J., Schneider, R. C., Guppy, M., Liggins, G. C., Hochachka, P. W., Elliott, R. E., and Zapol, W. M. (1985). Seal lungs collapse during free diving - evidence from arterial nitrogen tensions. Science 229, 556-558.

Fernandez, A., Edwards, J. F., Rodriguez, F., De Los Monteros, A. E., Herraez, P., Castro, P., Jaber, J. R., Martin, V., and Arbelo, M. (2005). "Gas and fat embolic syndrome" involving a mass stranding of beaked whales (Family Ziphiidae) exposed to anthropogenic sonar signals. Vet. Pathol. 42, 446-457.

Ferrigno, M., and Lundgren, C. E. G. (2003). "Breath-hold diving," in Physiology and Medicine of Diving, eds A. O. Brubakk and T. S. Neuman (Edinburgh: Saunders), 153-180.

Fick, R. (1911). Zum Streit um dem Gelenkdruck. Anat. Hefte. 43, 397.

Fitz-Clarke, J. R. (2009). Risk of decompression sickness in extreme human breath-hold diving. Undersea Hyperb. Med. 36, 83-91.

Francis, T. J. R., and Simon, J. M. (2003). "Pathology of decompression sickness," in Bennett and Elliott's
Physiology and Medicine of Diving, eds A. O. Brubakk and T. S. Neuman (Edinburgh: Saunders), 530-556.

Gannier, A. (1998). Variation saisonnière de l'affinité bathymétrique des cétacés dans le bassin Luguroprovençal (Méditerranée occidentale). Vie Milieu 48, 25-34.

Hamilton, R. W., and Thalmann, E. D. (2003). "Decompression practice," in Bennett and Elliott's Physiology and Medicine of Diving, eds A. O. Brubakk and T. S. Neuman (Edinburgh: Saunders), 455-500.

Harris, M., Berg, W. E., Whitaker, D. M., Twitty, V. C., and Blinks, L. R. (1945). Carbon dioxide as a facilitating agent in the initiation and growth of bubbles in animals decompressed to simulated altitudes. J. Gen. Physiol. 28, 225-240.

Harvey, E. N. (1945). Decompression sickness and bubble formation in blood and tissues. Bull. N. Y. Acad. Med. 21, 505-536.

Hayward, A. T. J. (1967). Tribonucleation of bubbles. Br. J. Appl. Phys. 18, 641-644.

Hennessy, T. R. (1989). “On the site, origin, evolution and effects of decompression," in Supersaturation and bubble formation in fluids and organisms, eds A. O. Brubakk, B. B. Hemmingsen and G. Sundnes (Trondheim: The Royal Norwegian Society of Sciences and Letters, The Foundation), 291-340.

Hooker, S., and Baird, R. W. (1999). Deep-diving behaviour of the northern bottlenose whale, Hyperoodon ampullatus (Cetacea: Ziphiidae). Proc. Biol. Sci. 266, 671-676.

Hooker, S. K., Baird, R. W., and Fahlman, A. (2009). Could beaked whales get the bends? Effect of diving behaviour and physiology on modelled gas exchange for three species: Ziphius cavirostris, Mesoplodon densirostris and Hyperoodon ampullatus. Respir. Physiol. Neurobiol. 167, 235-246.

Hooker, S. K., Fahlman, A., Moore, M. J., Aguilar De Soto, N., Bernaldo De Quiros, Y., Brubakk, A. O., Costa, D. P., Costidis, A. M., Dennison, S., Falke, K. J., Fernandez, A., Ferrigno, M., Fitz-Clarke, J. R., Garner, M. M., Houser, D. S., Jepson, P. D., Ketten, D. R., Kvadsheim, P. H., Madsen, P. T., Pollock, N. W., Rotstein, D. S., Rowles, T. K., Simmons, S. E., Van Bonn, W., Weathersby, P. K., Weise, M. J., Williams, T. M., and Tyack, P. L. (2012). Deadly diving? Physiological and behavioural management of decompression stress in diving mammals. Proc. R. Soc. B Biol. Sci. 279, 1041-1050.
Houser, D. S., Dankiewicz-Talmadge, L. A., Stockard, T. K., and Ponganis, P. J. (2010). Investigation of the potential for vascular bubble formation in a repetitively diving dolphin. J. Exp. Biol. 213, 52-62.

Houser, D. S., Howard, R., and Ridgway, S. (2001). Can diving-induced tissue nitrogen supersaturation increase the chance of acoustically driven bubble growth in marine mammals? J. Theor. Biol. 213, 183-195.

Ikels, K. G. (1970). Production of gas bubbles in fluids by tribonucleation. J. Appl. Phys. 28, 524-527.

Ishiyama, A. (1983). Analysis of gas composition of intra vascular bubbles produced by decompression. Bull. Tokyo Med. Dent. Univ. 30, 25-36.

Jepson, P. D., Arbelo, M., Deaville, R., Patterson, I. A. P., Castro, P. Baker, J. R., Degollada, E., Ross, H. M., Herraez, P., Pocknell, A. M. Rodriguez, F., Howie, F. E., Espinosa, A., Reid, R. J., Jaber, J. R., Martin, V., Cunningham, A. A., and Fernandez, A. (2003). Gas-bubble lesions in stranded cetaceans - was sonar responsible for a spate of whale deaths after an Atlantic military exercise? Nature 425, 575-576.

Jepson, P. D., Deaville, R., Patterson, I. A. P., Pocknell, A. M., Ross, H. M., Baker, J. R., Howie, F. E., Reid, R. J., Colloff, A., and Cunningham, A. A. (2005). Acute and chronic gas bubble lesions in cetaceans stranded in the United Kingdom. Vet. Pathol. 42, 291-305.

Keil, W., Bretsxhneider, K., Patzelt, D., Behning, I., Lignitz, E., and Matz, J. (1980). Luftembolie oder Fäulnisgas? Zur Dianostik der cardialen Luftembolie an der Leiche. Beitr. Gerichtl. Med. 38, 395-408.

King, J. M., Dodd, D. C., Newson, M. E., and Roth, L. (1989). The Necropsy Book. Ithaca: Charles Louis Davis, D.V.M. Foundation.

Knight, B. (1996). Forensic Pathology. London: Arnold.

Kooyman, G. L. (1973). Respiratory adaptations in marine mammals. Am. Zool. 13, 457-468.

Kooyman, G. L., and Ponganis, P. J. (1998). The physiological basis of diving to depth: birds and mammals. Annu. Rev. Physiol. 60, 19-32.

Kooyman, G. L., and Sinnett, E. E. (1982). Pulmonary shunts in harbor seals and sea lions during simulated dives to depth. Physiol. Zool. 55, 105-111.

Kuiken, T., and García-Hartmann, M. (1991). "Dissection techniques and tissues sampling," in 1st European
Cetacean Society Workshop on Cetacean Pathology, Vol. 17, Leiden.

Lawrence, C. (1997). Interpretation of gas in diving autopsies. SPUMS J. 27, 228-230.

Lawrence, C., and Cooke, C. (2006). Autopsy and the investigation of scuba diving fatalities. Diving Hyperb. Med. 36, 2-8.

Lerner, L., and Lerner, B. W. (2006). Decomposition. Available at: http:// www.enotes.com/forensic-science/ decomposition [accessed November 30, 2010].

Martin, V., Servidio, A., Tejedor, M., Arbelo, M., Brederlau, B., Neves, S., Perez-Gil, M., Urquiola, E., PerezGil, E., and Fernandez, A. (2009). "Cetaceans and conservation in the Canary Islands," in 18th Biennial Conference on the Biology of Marine Mammals. Quebec, Canada, 153.

Mazzariol, S., Di Guardo, G., Petrella, A., Marsili, L., Fossi, C. M., Leonzio, C., Zizzo, N., Vizzini, S., Gaspari, S., Pavan, G., Podestà, M., Garibaldi, F., Ferrante, M., Copat, C., Traversa D., Marcer, F., Airoldi, S., Frantzis, A., Bernaldo De Quirós, Y., Cozzi, B., and Fernández, A. (2011). Sometimes sperm whales (Physeter macrocephalus) cannot find their way back to the high seas: a multidisciplinary study on a mass stranding. PLoS ONE 6, e19417. doi:10.1371/journal.pone.0019417

Mcdonough, P. M., and Hemmingsen, E. A. (1984a). Bubble formation in crabs induced by limb motions after decompression. J. Appl. Phys. 57, 117-122.

Mcdonough, P. M., and Hemmingsen, E. A. (1984b). Bubble formation in curstaceans following decompression from hyperbaric gas exposures. J. Appl. Phys. 56, 513-519.

Mcdonough, P. M., and Hemmingsen, B. B. (1985a). A direct test for the survival of gaseous nuclei in vivo. Aviat. Space Environ. Med. 56, 54-56. Mcdonough, P. M., and Hemmingsen, E. A. (1985b). Swimming movements initiate bubble formation in fish decompressed from elevated gas-pressures. Comp. Biochem. Physiol. A. Comp. Physiol. 81, 209-212.

Moore, M. J., Bogomolni, A. L., Dennison, S. E., Early, G., Garner, M. M., Hayward, B. A., Lentell, B. J., and Rotstein, D. S. (2009). Gas bubbles in seals, dolphins, and porpoises entangled and drowned at depth in gillnets. Vet. Pathol. 46, 536-547.

Moore, M. J., and Early, G. A. (2004). Cumulative sperm whale bone damage and the bends. Science 306, 2215-2215. 
Moore, M. J., Hammar, T., Arruda, J., Cramer, S., Dennison, S., Montie, E., and Fahlman, A. (2011). Hyperbaric computed tomographic measurement of lung compression in seals and dolphins. J. Exp. Biol. 214, 2390-2397.

Muth, C. M., and Shank, E. S. (2000). Primary care: gas embolism. New Engl. J. Med. 342, 476-482.

Paulev, P. (1965). Decompression sickness following repeated breath-hold dives. J. Appl. Physiol. 20, 1028.

Piantadosi, C. A., and Thalmann, E. D. (2004). Pathology: whales, sonar and decompression sickness. Nature 428, 1-716; discussion 712-716.

Pierucci, G., and Gherson, G. (1968). Experimental study on gas embolism with special reference to the differentiation between embolic gas and putrefaction gas. Zacchia 4, 347-373.

Pierucci, G., and Gherson, G. (1969). Further contribution to the chemical diagnosis of gas embolism. The demonstration of hydrogen as an expression of "putrefactive component.” Zacchia 5, 595-603.

Ponganis, P. J., Kooyman, G. L., and Ridgway, S. (2003). "Comparative diving physiology," in Physiology and Medicine of Diving, eds A. O. Brubakk and T. S. Neuman (Edinburgh: Saunders), 211-226.

Ridgway, S. H., and Howard, R. (1979). Dolphin lung collapse and intramuscular circulation during free diving - evidence from nitrogen washout. Science 206, 1182-1183.

Schipke, J. D., Gams, E., and Kallweit, O. (2006). Decompression sickness following breath-hold diving. Res. Sports Med. 14, 163-178.

Scholander, P. F. (1940). Experimental investigations on the respiratory function in diving mammals and birds. Hvalradets Skrifter 22, 1-131.

Schorr, G. S., Falcone, E. A., Moretti, D. J., McCarthy, E. M., Hanson, M. B., and Andrews, R. D. (2011). "The bar is really noisy, but the food must be good: high site fidelity and dive behavior of Cuvier's beaked whales (Ziphius cavirostris) on an anti-submarine warfare range," in 19th biennial Conference on the Biology of Marine Mammals, Tampa, FL, 265

Smith-Sivertsen, J. (1976). "The origin of intravascular bubbles produced by decompression of rats killed prior to hyperbaric exposure," in Proceedings of the Fifth Symposium on Underwater Physiology, ed. C. J. Lambertsen (Bethesda: Federation of American Societies for Experimental Biology), 303-309.

Tikuisis, P., and Gerth, W. A. (2003). "Decompression theory," in Physiology and Medicine of Diving, eds A. O. Brubakk and T. S. Neuman (Edinburgh: Saunders), 419-454.

Tyack, P. L., Johnson, M., Soto, N. A., Sturlese, A., and Madsen, P. T. (2006). Extreme diving of beaked whales. J. Exp. Biol. 209, 4238-4253.

Tyack, P. L., Zimmer, W. M. X., Moretti, D., Southall, B. L., Claridge, D. E., Durban, J. W., Clark, C. W., D'Amico, A., Dimarzio, N., Jarvis, S., Mccarthy, E., Morrissey, R., Ward, J., and Boyd, I. L. (2011). Beaked whales respond to simulated and actual navy sonar. PLoS ONE 6, e17009. doi:10.1371/journal.pone.0017009

Unit of Cetaceans Research, U.L.P.G.C. (2006). Necropsies of Cetaceans Stranded in Canary Islands in 2006
Report. Las Palmas de Gran Canaria: Canary Islands Government.

Unit of Cetaceans Research, U.L.P.G.C. (2007). Necropsies of Cetaceans Stranded in Canary Islands in 2007 Report. Las Palmas de Gran Canaria: Canary Islands Government.

Unit of Cetaceans Research, U.L.P.G.C. (2008). Necropsies of Cetaceans Stranded in Canary Islands in 2008 Report. Las Palmas de Gran Canaria: Canary Islands Government.

Unit of Cetaceans Research, U.L.P.G.C. (2009). Necropsies of Cetaceans Stranded in Canary Islands in 2009 Report. Las Palmas de Gran Canaria: Canary Islands Government.

Unit of Cetaceans Research, U.L.P.G.C. (2010). Necropsies of Cetaceans Stranded in Canary Islands in 2010 Report. Las Palmas de Gran Canaria: Canary Islands Government.

Vann, R. D., Butler, F. K., Mitchell, S. J. and Moon, R. E. (2011). Decompression illness. Lancet 377, 153-164.

Vass, A. A., Barshick, S. A., Sega, G., Caton, J., Skeen, J. T., Love, J. C., and Synstelien, J. A. (2002). Decomposition chemistry of human remains: a new methodology for determining the postmortem interval. J. Forensic Sci. 47, 542-553.

Watwood, S. L., Miller, P. O., Johnson, M., Madsen, J., and Tyack, P. L. (2006). Deep-diving foraging behaviour of sperm whales (Physeter macrocephalus). J. Anim. Ecol. 75 814-825.

West, K. L., Walker, W. A., Baird, R. W., White, W., Levine, G., Brown, E., and Schofield, D. (2009). Diet of pygmy sperm whales (Kogia breviceps) in the Hawaiian archipelago. Mar. Mamm. Sci. 25, 931-943.

Wheen, L. C., and Williams, M. P. (2009). Post-mortems in recreational scuba diver deaths: the utility of radiology. J. Forensic Leg. Med. 16, 273-276.

Williams, T. M., and Worthy, G. A. J. (2002). "Anatomy and physiology: the challenge of aquatic living," in Marine Mammal Biology, ed. A. R. Hoelzel (Oxford: Blackwell Science), 73-97.

Zimmer, W. M. X., and Tyack, P. L. (2007). Repetitive shallow dives pose decompression risk in deep-diving beaked whales. Mar. Mamm. Sci. 23, 888-925.

Conflict of Interest Statement: The authors declare that the research was conducted in the absence of any commercial or financial relationships that could be construed as a potential conflict of interest.

Received: 03 February 2012; accepted: 14 May 2012; published online: 04 June 2012.

Citation: de Quirós YB, GonzálezDiaz O, Arbelo $M$, Sierra E, Sacchini $S$ and Fernández A (2012) Decompression vs. decomposition: distribution, amount, and gas composition of bubbles in stranded marine mammals. Front. Physio. 3:177. doi: 10.3389/fphys.2012.00177

This article was submitted to Frontiers in Aquatic Physiology, a specialty of Frontiers in Physiology.

Copyright (c) 2012 de Quirós, GonzálezDiaz, Arbelo, Sierra, Sacchini and Fernández. This is an open-access article distributed under the terms of the Creative Commons Attribution Non Commercial License, which permits noncommercial use, distribution, and reproduction in other forums, provided the original authors and source are credited. 